\title{
The neurological sequelae of pandemics and epidemics
}

\author{
Fernanda Valerio $^{1}\left({ }^{10} \cdot\right.$ Daniel P. Whitehouse $^{1} \cdot$ David K. Menon $^{1,2} \cdot$ Virginia F. J. Newcombe ${ }^{1,2}$
}

Received: 30 June 2020 / Revised: 3 October 2020 / Accepted: 7 October 2020 / Published online: 26 October 2020

(c) The Author(s) 2020

\begin{abstract}
Neurological manifestations in pandemics frequently cause short and long-term consequences which are frequently overlooked. Despite advances in the treatment of infectious diseases, nervous system involvement remains a challenge, with limited treatments often available. The under-recognition of neurological manifestations may lead to an increase in the burden of acute disease as well as secondary complications with long-term consequences. Nervous system infection or dysfunction during pandemics is common and its enduring consequences, especially among vulnerable populations, are frequently forgotten. An improved understanding the possible mechanisms of neurological damage during epidemics, and increased recognition of the possible manifestations is fundamental to bring insights when dealing with future outbreaks. To reverse this gap in knowledge, we reviewed all the pandemics, large and important epidemics of human history in which neurological manifestations are evident, and described the possible physiological processes that leads to the adverse sequelae caused or triggered by those pathogens.
\end{abstract}

Keywords CNS infections $\cdot$ Peripheral neuropathies $\cdot$ Pandemics/history $\cdot$ Meningitis $\cdot$ Encephalitis

\section{Introduction}

Pandemics are large-scale outbreaks of infectious disease that can cause an excess in morbidity and mortality globally, or at least over a wide geographic area, and lead to socioeconomic disruption. Increase in global travel, urbanisation, climate change, environmental degradation, displacement and consumption of wild animals are factors thought to have increased the likelihood of pandemics during the past century [79]. The majority of pathogens responsible for outbreaks can cause neurologic illness, which are frequently overlooked, under-reported and under-diagnosed. Even in tertiary centres of developed countries, up to $30 \%$ of patients with a CNS infection never receive an etiological diagnosis [135], and in low resource settings lacking diagnostic tools, neurological manifestations are often poorly characterised. Aside from the associated mortality, neurological

Fernanda Valerio

fv274@cam.ac.uk

1 University Division of Anaesthesia, Addenbrooke's Hospital, University of Cambridge, Box 93, Hills Road, Cambridge CB2 0QQ, UK

2 Wolfson Brain Imaging Centre, University of Cambridge, Cambridge, UK involvement of infectious disease can lead to prolonged hospital stay and significantly increase rehabilitation time and long-term care needs after discharge [135], posing a far-reaching socioeconomic burden.

As the world deals with the Sars-CoV2 pandemic, reports of neurologic manifestations have increased. Understanding neurological complications of previous pandemics, and the pathophysiological mechanisms that underlie them, are fundamental to place the current situation in perspective, and help address the enduring consequences once current waves of acute infection subside. This narrative review assesses the neurological manifestations of past and current pandemics, to aid our understanding of the current pandemic and prepare for future outbreaks.

\section{Mechanisms of pathogen-mediated neurological disease}

Pathogens can lead to nervous system impairment through multiple mechanisms. There may be direct infection and replication leading to the clinical syndromes of encephalitis, myelitis and meningitis [65]. Para-infectious complications such as sepsis and metabolic dysfunction related and coagulopathy can lead to encephalopathy and vascular events. 
The infection can also trigger an indirect immune-mediated attack both in the central and peripheral nervous system [32], as seen in Guillain-Barré syndromes (GBS) or acute disseminated encephalomyelitis (ADEM). Finally, some viruses can persist mutated or latent in the central nervous system (CNS) or peripheral ganglia, leading to potential late reactivation and clinical disease. Further details are provided in Table 1; Fig. 1.

\section{Pathogens responsible for pandemics and important epidemics throughout history}

Pathogens are divided according to the main mode of transmission (vector-borne, water/food-borne and direct or indirect with infected individuals). Its features, including notable pandemics, non-neurological and neurological manifestations may be found in Fig. 2 and Table 2. We have summarised imaging and laboratory findings in Table 3. A more complete description of the neurological manifestations follows.

\section{Vector-borne}

\section{Bubonic plague}

The first Plague pandemic, known as the Plague of Justinian, occurred during the sixth century and is believed to have hastened the end of the Roman Empire. The second commenced with a wave known as the "Black Death" and is estimated to have resulted in the deaths of over 100 million people; the highest of any pandemic in history. Currently, most human cases are located in Africa, and annual epidemics are reported in Madagascar [156]. Meningitis is reported in up to $7 \%$ of all patients, typically after the 1 st week in those who received incomplete or delayed treatment for the bubonic form. Younger patients have higher incidence of Yersinia meningitis (around $11 \%$ of children) $[8,14,82]$. It presents as a bacterial meningitis, with neutrophilic pleocytosis in the CSF. The gold standard for diagnosis is the culture of $Y$. pestis in blood, sputum, bubo aspirate or CSF, but the bacteria can also be detected using point of care testing with immunochromatographic assays or quantitative PCR in portable thermocyclers $[35,158]$.

\section{West Nile virus (WNV)}

This virus was first identified in the West Nile province of Uganda in 1937 [122]. In 1999 an outbreak occurred in New York which spread to the rest of the Americas, leading to the largest epidemics of meningitis or encephalitis ever reported in the western hemisphere [69]. Under $1 \%$ of infected individuals developed the neuroinvasive disease, but the incidence is higher among those $>65$ years, which also have higher mortality. The neurologic syndromes can overlap and be divided in meningitis, meningoencephalitis, and acute flaccid paralysis secondary to anterior myelitis and typically occurs in the acute phase of the disease. Extrapyramidal signs are seen in some encephalitic cases during the acute illness, and may be transient or last months after the resolution of the disease. Seizures and encephalopathy have also been reported [123].

\section{Japanese encephalitis}

Large epidemics of Japanese encephalitis Virus (JEV) occur every 2-15 years in South-East Asia and Western Pacific, making it the world's most commonly diagnosed epidemic encephalitis ( 70,000 cases/year). Among the arthropodborne viruses, JEV leads to the greatest loss of disabilityadjusted life years, due to the frequent neurological sequelae of the condition. While the majority of infections are asymptomatic or mild, $0.1-1 \%$ cause encephalitis, mainly in children. It manifests in the acute phase of the disease. Symptoms include impaired consciousness, headache, vomiting, and seizures. Pyramidal and extrapyramidal signs, involvement of cranial nerves, eye movement abnormalities and anterior myelitis are described. Similar neurological features are seen in adults. Other immunological manifestations include GBS, ADEM, transverse myelitis and $N$-methylD-aspartate (NMDA) receptor encephalitis, weeks after the onset of the viral illness. Approximately one-fifth of patients with JEV-encephalitis die and $44 \%$ of those with neurological involvement have incomplete recovery [140].

\section{Zika}

The Zika virus was described in Uganda in 1947 and has caused outbreaks in Asia and the Pacific. In 2014-2016 it caused an epidemic of microcephaly among newborns in the northeast of Brazil [31]. The congenital Zika syndrome occurs in $5-14 \%$ of pregnancies of infected mothers, and includes severe microcephaly, skull collapse, subcortical calcifications, corpus callosum anomalies, decreased white matter, ventriculomegaly, cerebral cortex thinning, abnormal gyral patterns, vermis hypoplasia, chorioretinal atrophy, focal pigmented mottling of the retina, optic nerve atrophy and congenital contractures [90, 94]. Zika virus-associated GBS (both axonal and demyelinating) has been described 5-15 days after the acute disease [94].

\section{Chikungunya fever}

Chikungunya virus was isolated during an outbreak in 1952 in Tanzania, and significant epidemics have been described 
Table 1 Mechanisms of pathogen-induced neurological injury

Mechanisms Description

Neurologic manifestations

\section{Direct invasion}

Blood brain barrier (BBB) (haematological entry)

Peripheral nerves (trans-synaptic spread)

\section{Para-infectious}

Sepsis-associated

Secondary to metabolic dysfunction

Secondary to coagulopathy and vasculitis

\section{Post-infectious}

Autoimmune
Penetration of endothelial barriers via (BBB disruption associated with acute host inflammatory responses may facilitate invasion):

Transcellular penetration (using pinocytosis or receptor-mediated entry)

Paracellular entry (by disrupting tight junctions)

Via entry of infected leukocytes from the peripheral circulation into the CNS (Trojan horse mechanism) [28, 65]

Pathogens:

Move along peripheral nerves via retrograde (from axon terminal to cell body) or anterograde (from cell body to axon terminal) transport

Invade the PNS by binding to receptors on axons of sensory, autonomic and motor neurons, including the olfactory and vagal nerves $[68,77,84,116,142]$

Diffuse disturbance of brain function as a consequence of the systemic inflammatory response of sepsis [45, 148]

Presents as impaired attention and arousal [165]

Release of inflammatory mediators affecting both the BBB and the cerebral microcirculation [120] ("cytokine storm")

Can be isolated or in the context of sepsis and organ failure:

Severe hypoxia

Shock-induced hypoperfusion

Metabolic disturbances

Electrolyte imbalances (hyponatremia or hypernatremia, hypocalcaemia or hypercalcemia)

Hyperinflammation in SIRS and sepsis leads to coagulopathy and a prothrombotic state Both direct pathogen invasion and the proinflammatory state of sepsis lead to endothelial damage [144], which then shifts to a procoagulant state and has increased vascular permeability $[57,126]$

Infections may cause vasculitis, either due to pathogen invasion, exaggerated immune response, or immune dysregulation triggered by bacterial toxins or antigens [136]

Triggered especially by viruses, which serve as antigenic stimulus and lead to lesions of the PNS and CNS

Associated with molecular mimicry between the pathogen and molecules on the axolemmal surface, glial membranes at the node of Ranvier [150] or myelin proteins of the host, which leads to T-cell activation and an autoimmune response [106]
Encephalitis

Meningoencephalitis

Meningitis

Anterior myelitis

Encephalopathy
Encephalopathy

Acute haemorrhagic leukoencephalitis (AHL)
Seizures

Encephalopathy

Diffuse ischaemia

\section{Stroke}

Cerebral venous thrombosis

Intracranial haemorrhage

Peripheral neuropathy
Guillain-Barré syndromes

Acute disseminated encephalomyelitis (ADEM)

Transverse myelitis

Acute motor axonal neuropathy (AMAN)

Acute inflammatory demyelinating polyneuropathy (AIDP) 
Table 1 (continued)

\begin{tabular}{lll}
\hline Mechanisms & Description & Neurologic manifestations \\
\hline Persistence and latency of viral infections & After direct invasion of the nervous system & Neurocognitive disorders (HIV) \\
& Persistent viral infections: continuous viral & Subacute sclerosing panencephalitis (measles) \\
& replication & \\
& Latent viral infections: dormant state with & \\
& minimal or no production of viral material \\
& [84].Can be reactivated upon host immuno- \\
& suppression, and the activation of both innate \\
& and adaptive immune system can disrupt \\
& CNS homeostasis [65] \\
\hline
\end{tabular}

$B B B$ blood-brain-barrier, $P N S$ peripheral nervous system, $C N S$ central nervous system, $A H L$ acute haemorrhagic leukoencephalitis, $A D E M$ acute disseminated encephalomyelitis, $H I V$ human immunodeficiency virus

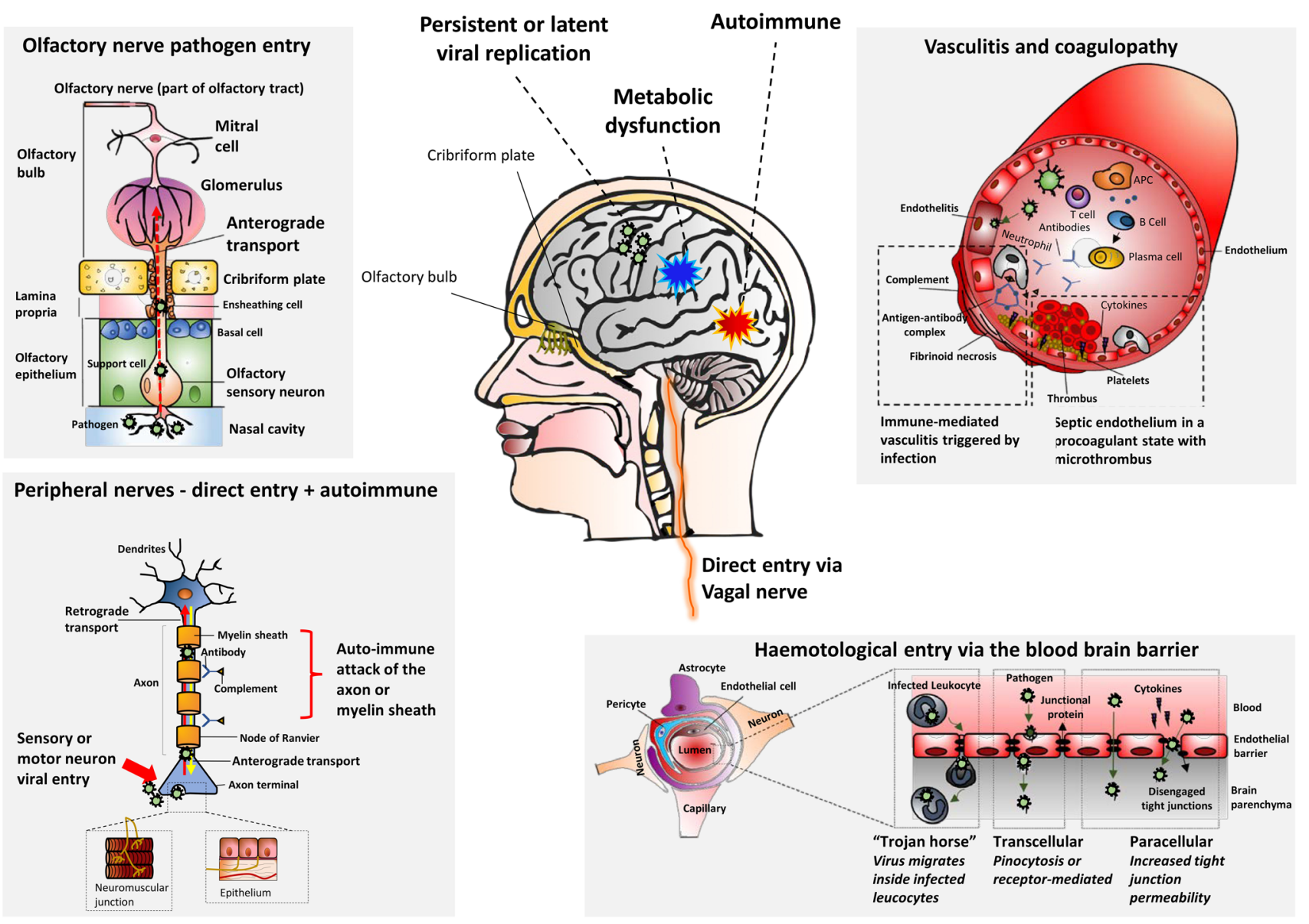

Fig. 1 Mechanisms of injury to the nervous system

worldwide. The most recent started in 2013, affecting the Southern USA, Mexico, Central and South America, with over 2 million infections reported [146]. Young children and older adults are at a higher risk of complications, which may affect approximately one percent of infected individuals. Encephalopathy and encephalitis are caused by direct viral invasion and manifest early during the infection [19]. Myelitis can occur either in the acute phase or later in the course of the disease. Tardive post-infectious complications, thought to be autoimmune in nature, include ADEM, optic neuropathy, GBS, brainstem encephalitis and Bickerstaff's encephalitis-Miller-Fisher overlap [19]. 


\section{Water or food-borne}

\section{Enteroviruses}

Enteroviruses cause over $90 \%$ of viral meningitis in children under 10 years and is most frequently by echoviruses and Coxsackie-B [77]. Two enteroviruses that caused epidemics and remarkable neurological manifestations are detailed below.

\section{Poliovirus}

Poliomyelitis was sporadically reported until the end of the nineteenth century, when large summer epidemics in North America and Europe began occurring annually [96]. The development and implementation of vaccination programmes since 1955 decreased its incidence dramatically, though outbreaks still occur in Africa and Asia, and it is endemic in Nigeria, Afghanistan and Pakistan. Around 1 in 150 infections will lead to paralytic poliomyelitis [96]. When the virus reaches the CNS, there is a meningitic phase followed by spinal poliomyelitis and onset of an acute flaccid paralysis secondary to anterior myelitis, early in the course of the infection. After a period of stable neurological function ( $\geq 15$ years), $30-40 \%$ of polio survivors develop progressive and persistent new muscle weakness and increased fatigue, characterising the post-polio syndrome. The pathogenesis is not completely understood but thought to be related to a disturbance of the denervation/re-innervation equilibrium with further denervation. In 2016, it was estimated that there are 15-20 million polio survivors worldwide [76].

\section{Enterovirus-71(EV71)}

This virus was isolated in 1969 and is a common cause of hand, foot, and mouth disease in children. Cyclical large epidemics occur in the Asian-Pacific region every 2-3 years and it circulates at a low level in the rest of the world, with small outbreaks in Europe, North America and Africa [130]. Children may develop CNS manifestations after 3-5 days of prodrome [100]. During an outbreak in Malaysia, $10-30 \%$ of hospitalised children had neurological manifestations, which included aseptic meningitis, encephalitis and acute flaccid

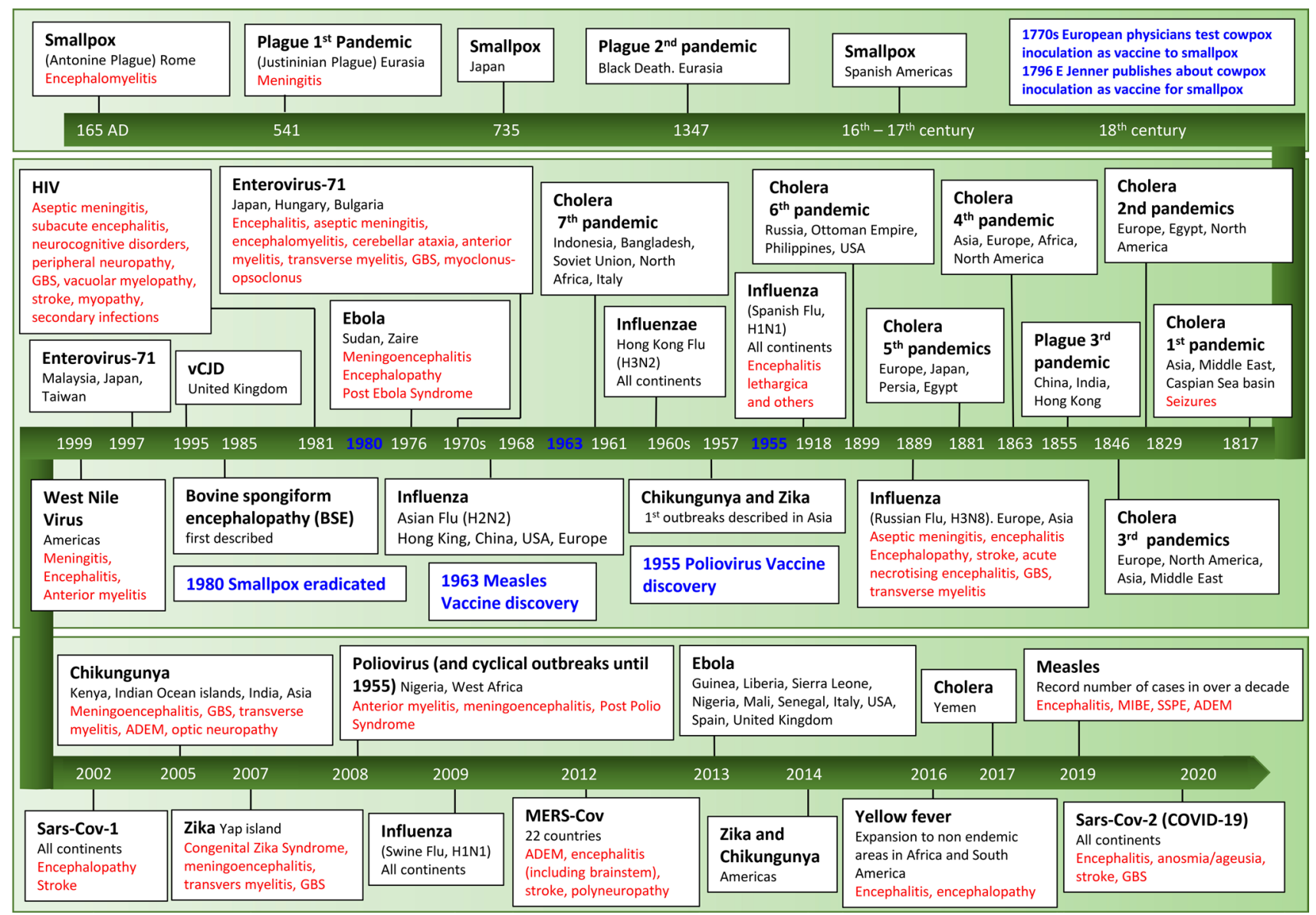

Fig. 2 Timeline of important pandemics including key neurological complications. These are noted for the first pandemic caused by an infection 


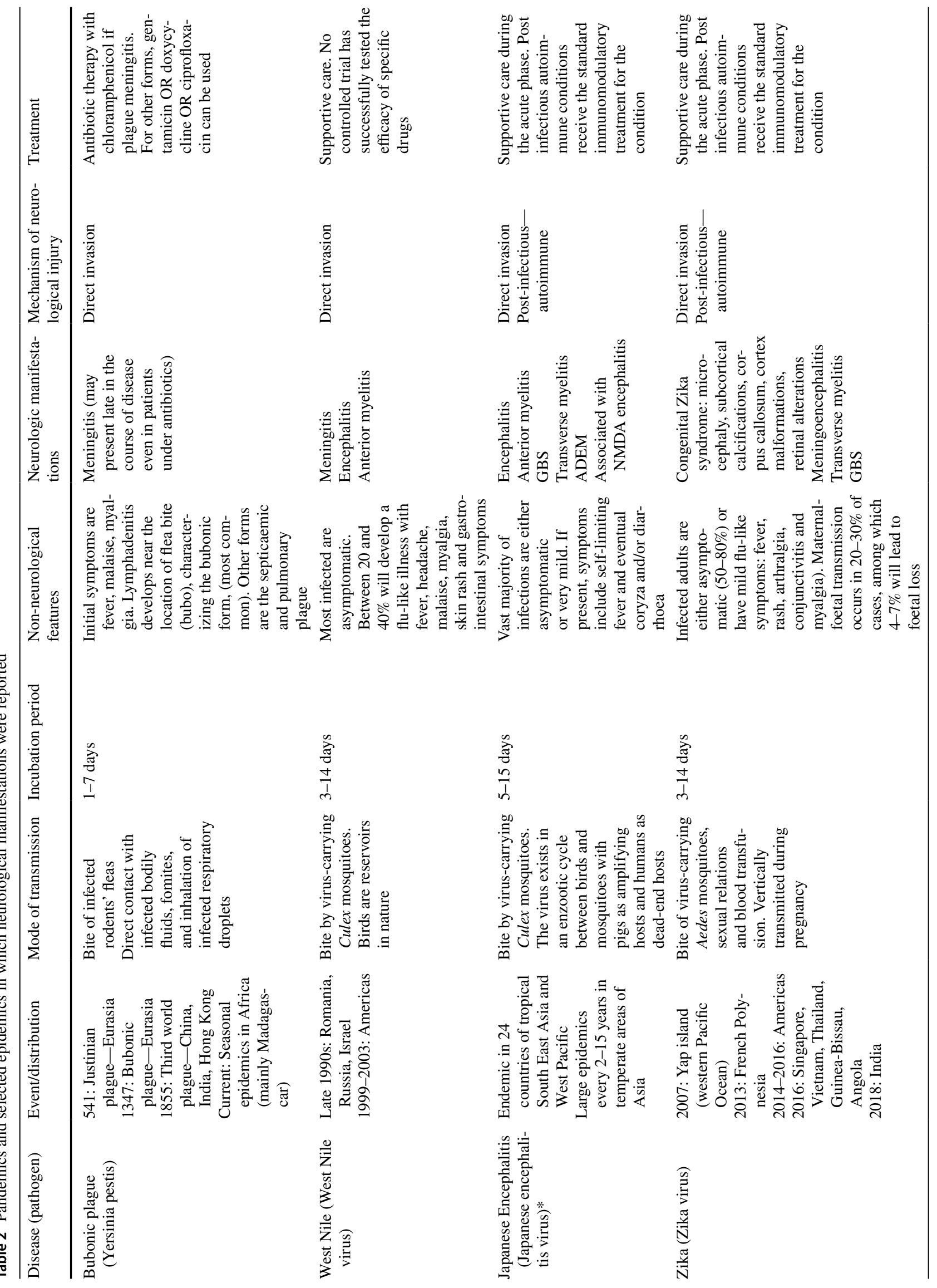




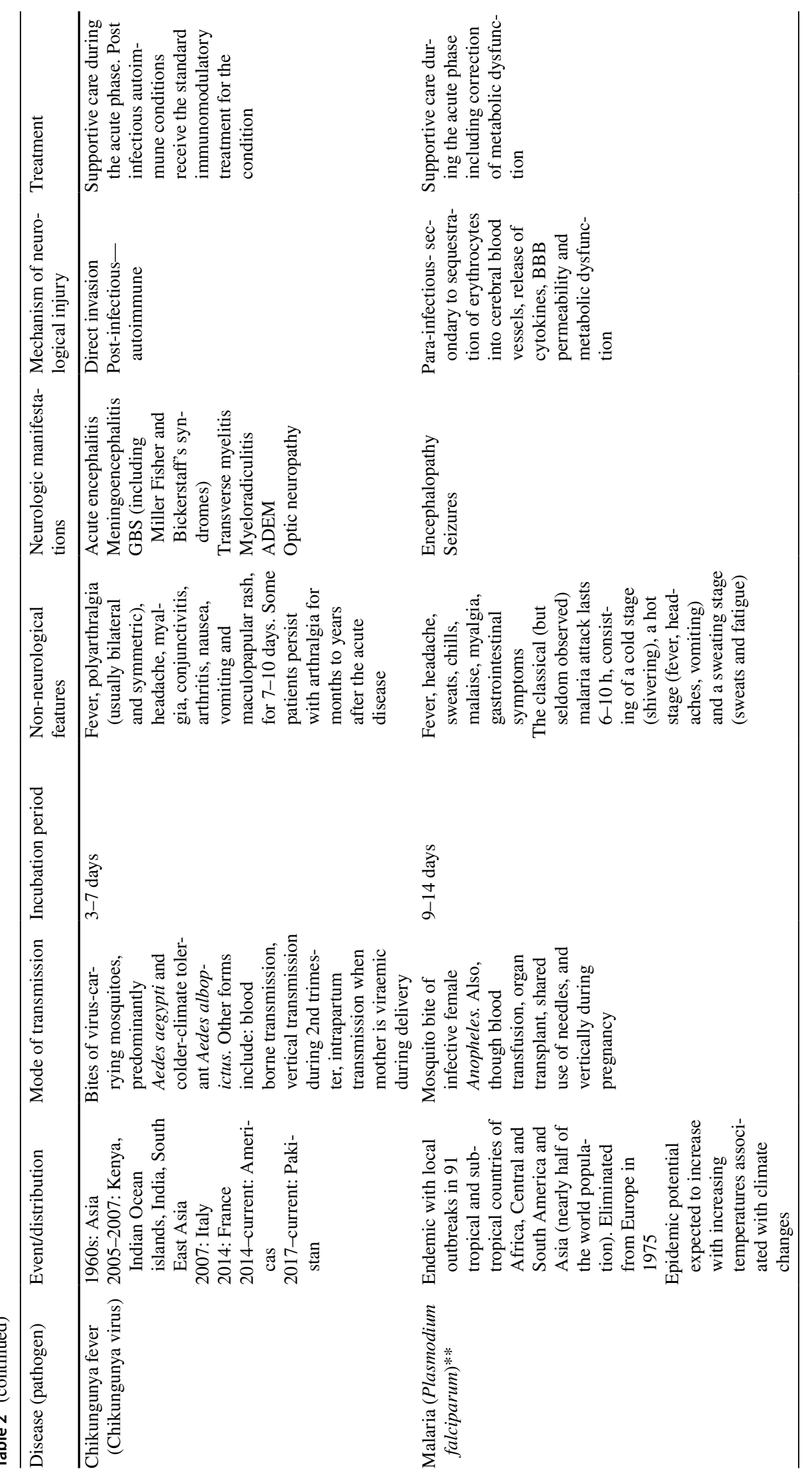




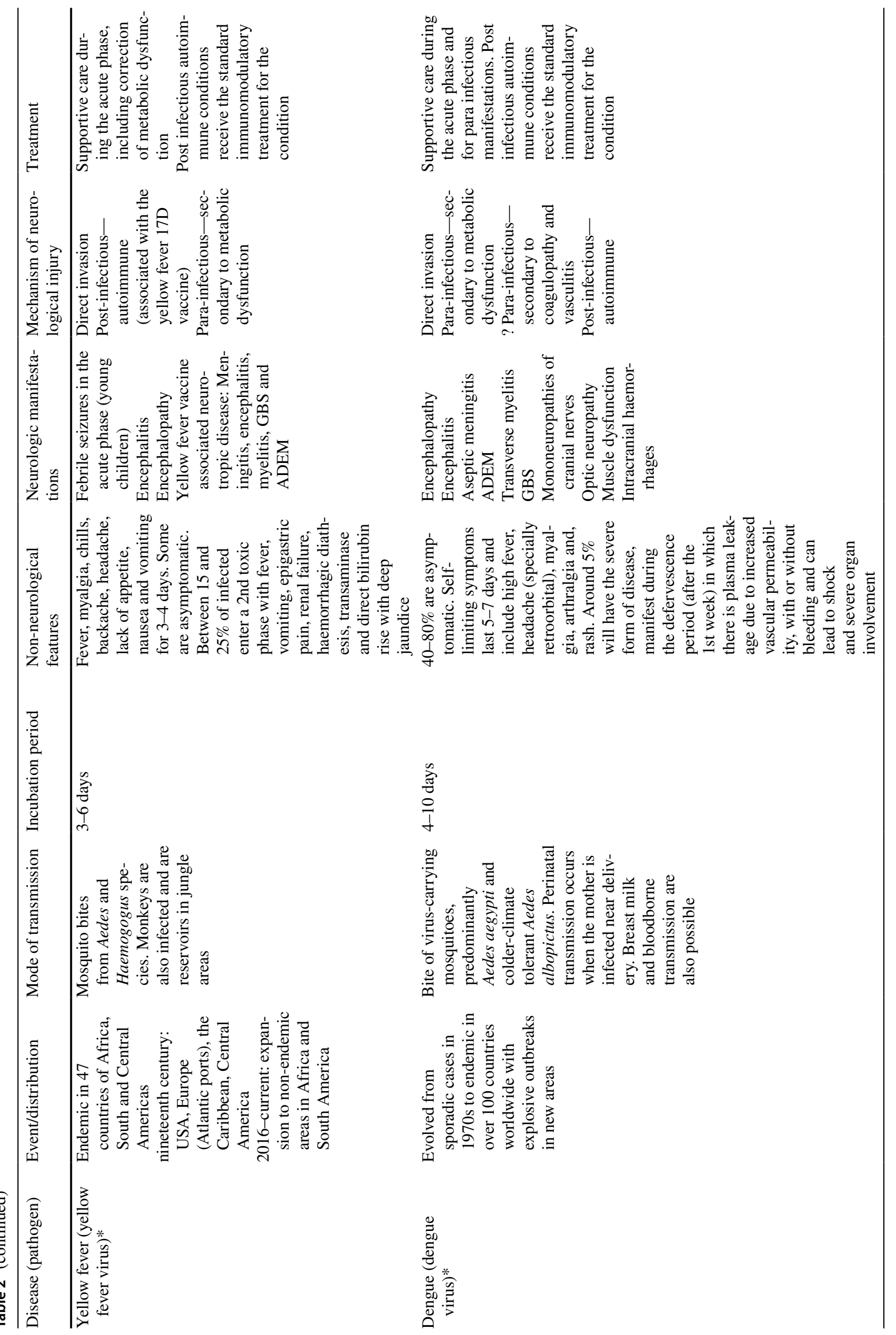




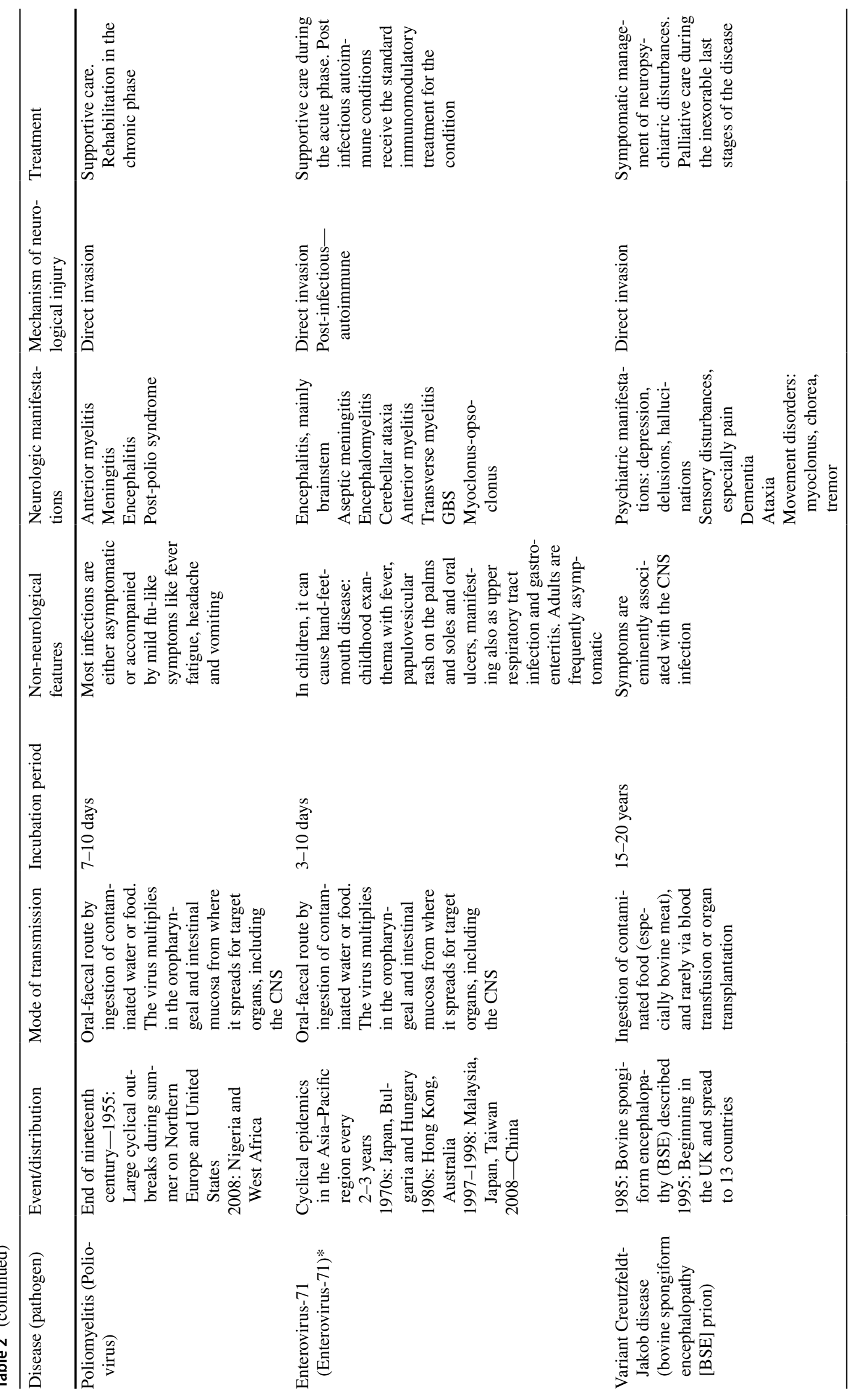




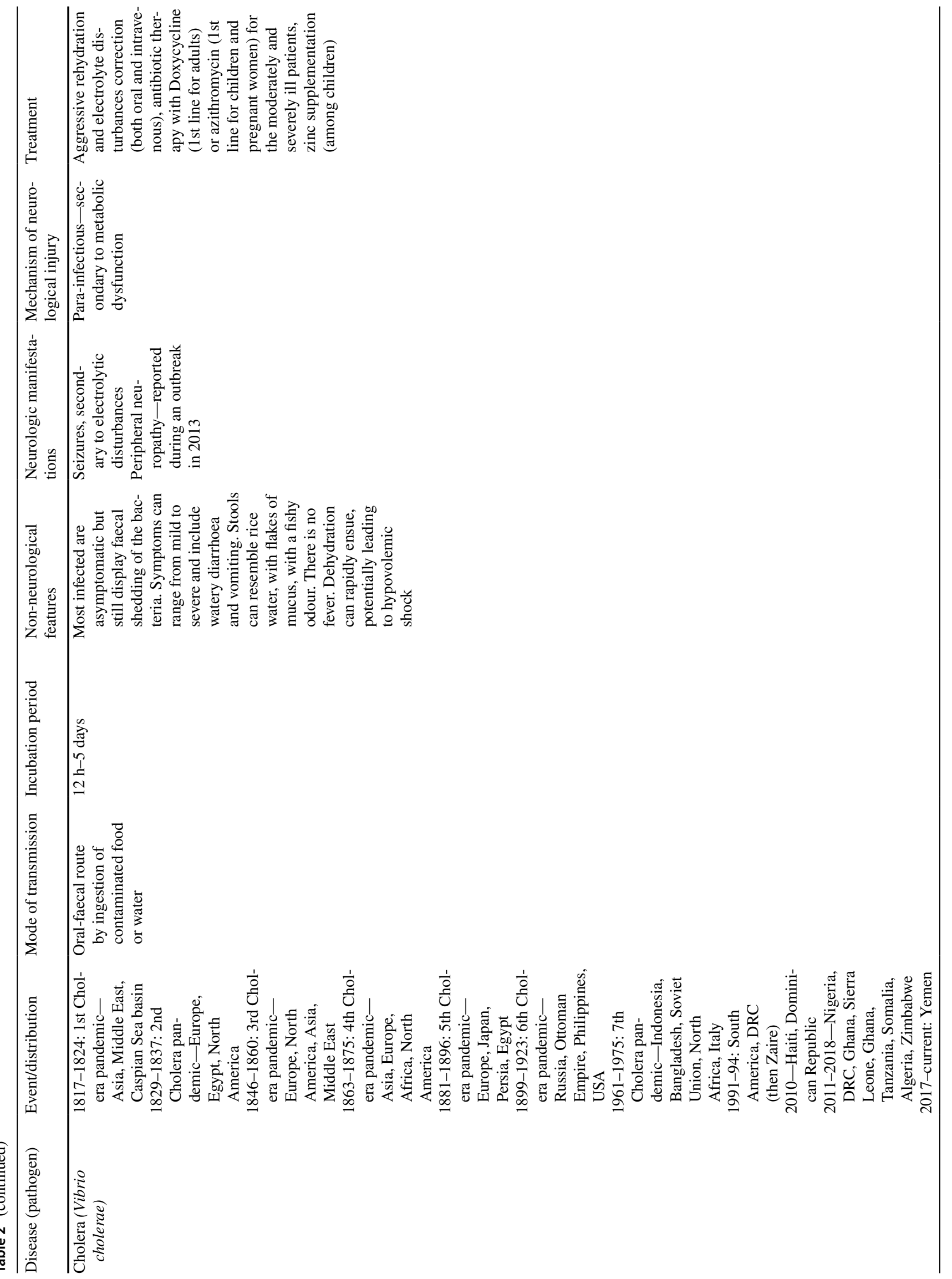




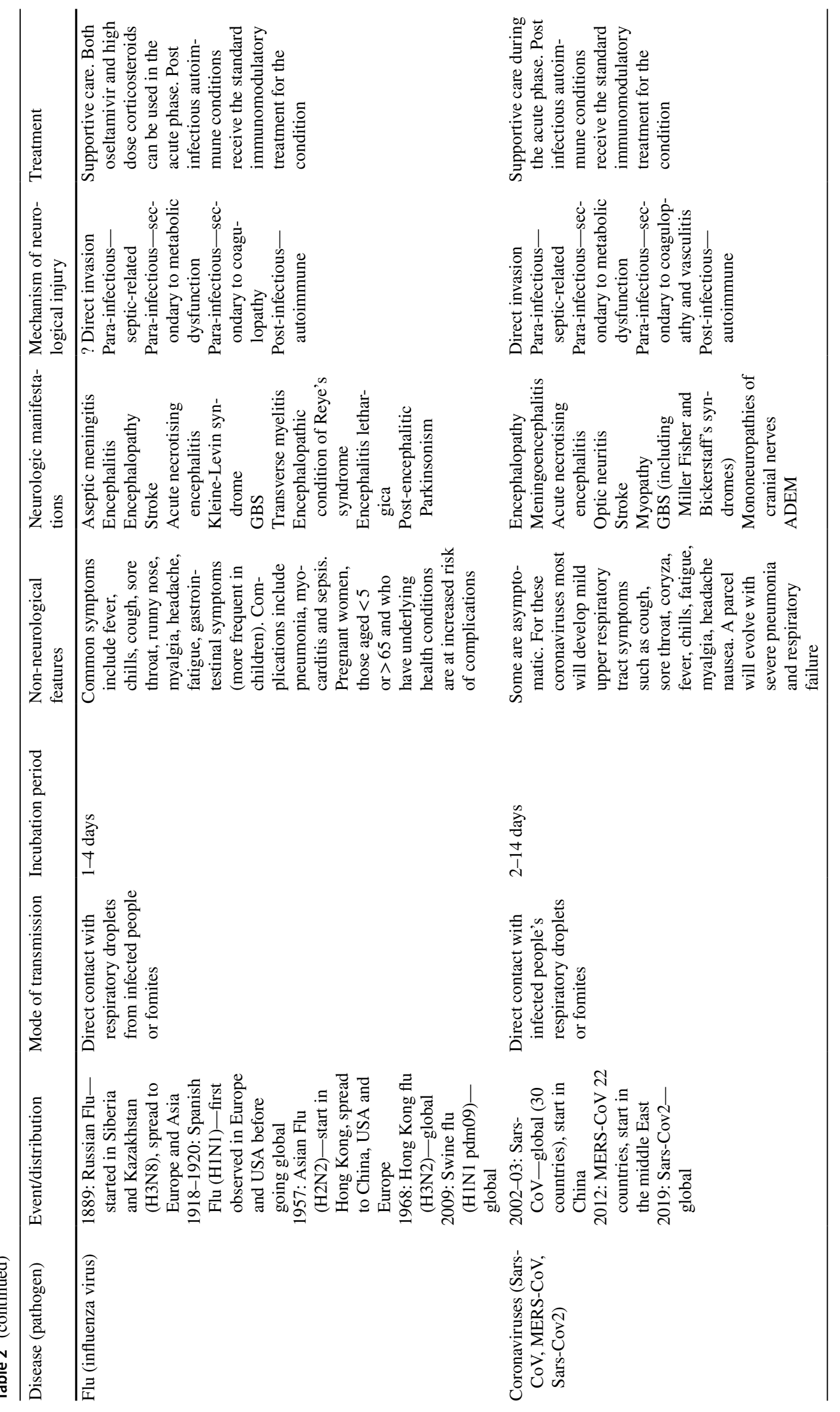




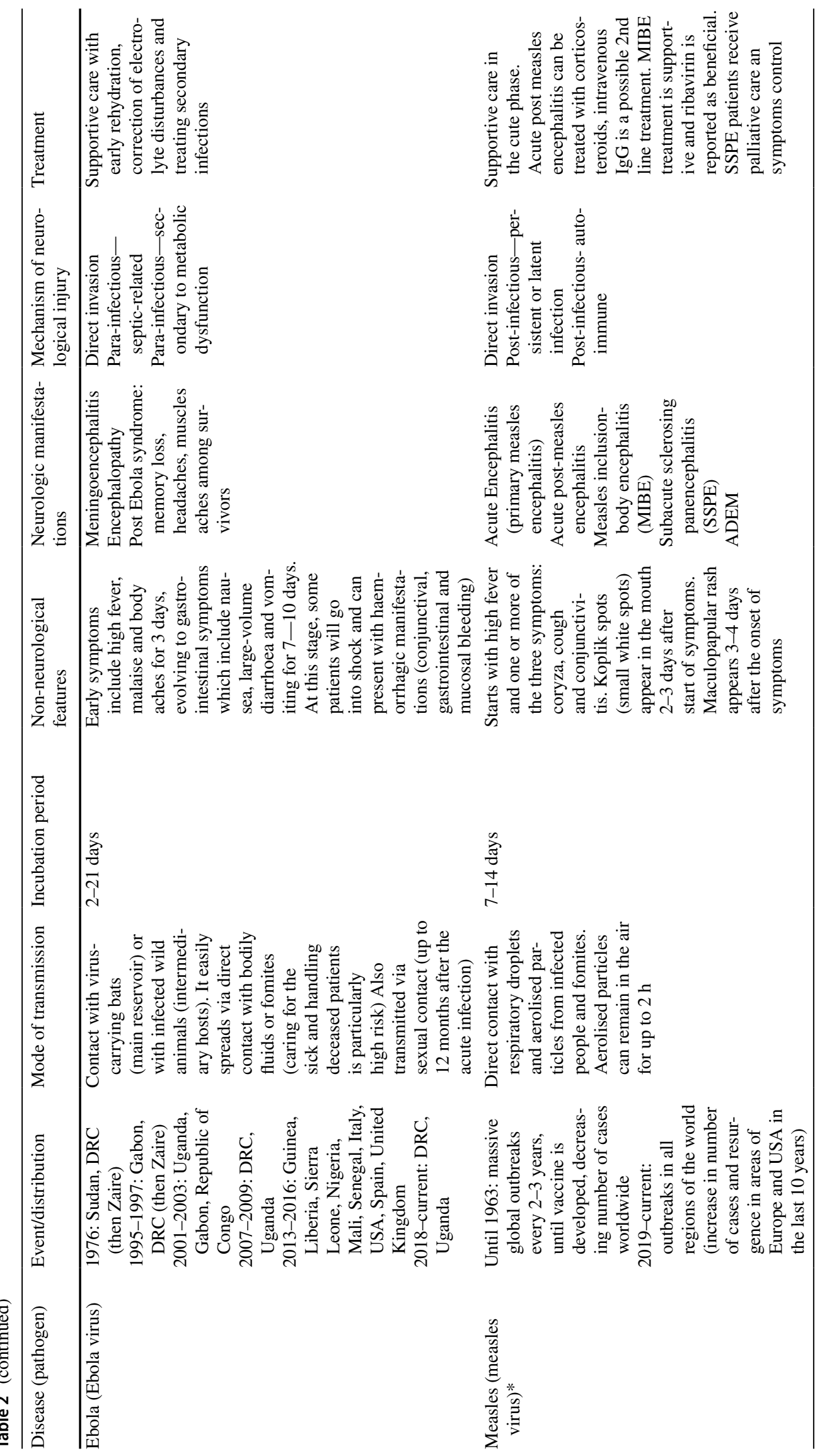




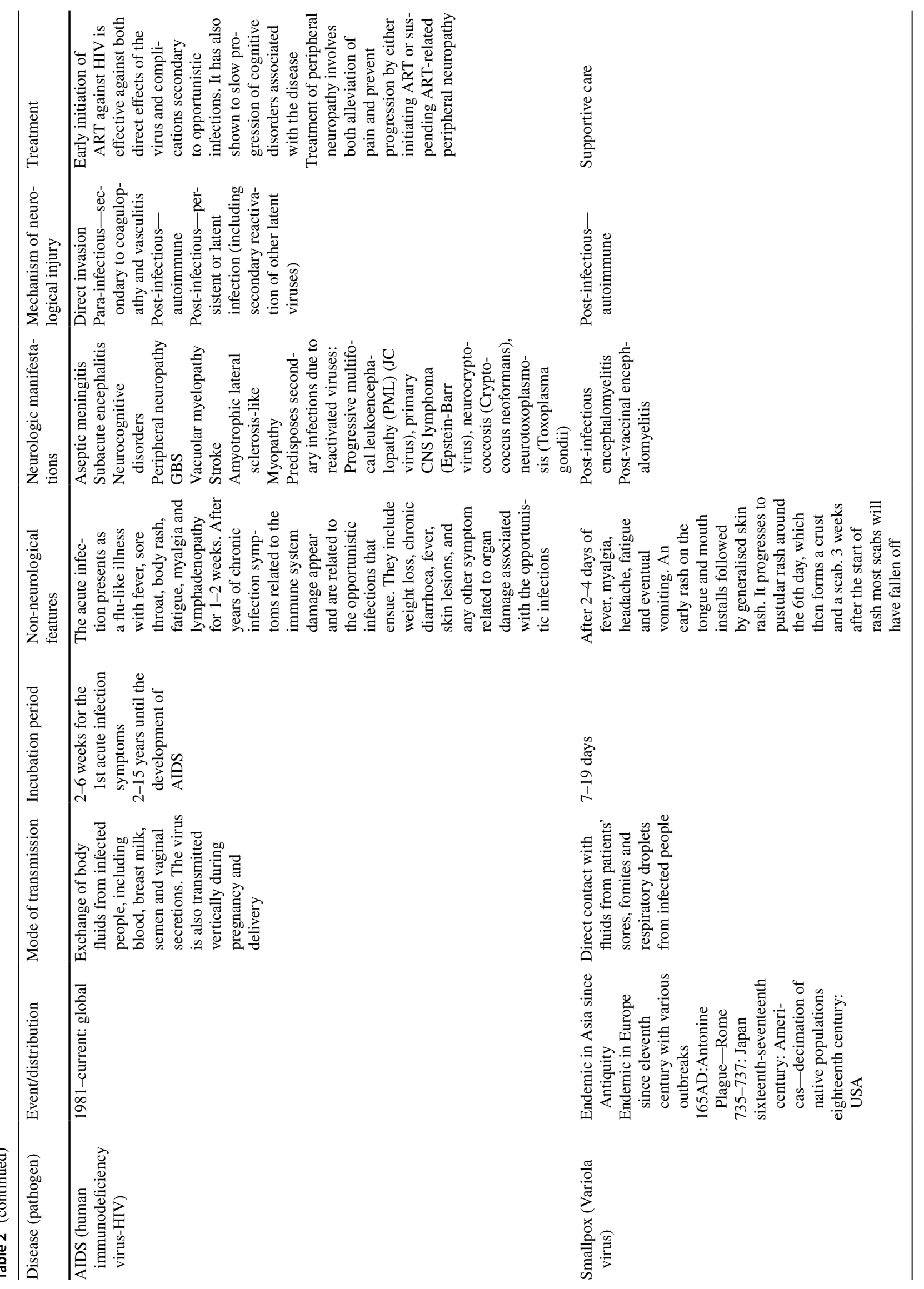


paralysis secondary to anterior myelitis, GBS and transverse myelitis [59]. The most common CNS manifestation is brainstem encephalitis, severely affecting the medulla and frequently evolving to cardiac dysfunction and neurogenic pulmonary oedema. Seizures may occur in children under two years. Myoclonic jerks are frequent in encephalitic cases. Up to one-fifth of children with severe neurological manifestations have sequelae, and only a quarter of those with brainstem encephalitis and cardiorespiratory failure have a full neurological recovery [20].

\section{Variant Creutzfeldt-Jakob (vCJD)}

Bovine spongiform encephalopathy (BSE) was first described in 1985 and peaked in 1992/1993. The first cases of vCJD in humans were described in 1995 in the UK [149], and were found to be caused by the BSE prion [26]. vCJD affects a younger age group when compared to sporadic CJD with a median onset age of 26 years in the UK and 36 years in France [15]. The incubation period may be as long as 15-20 years [27]. In the earliest phase of vCJD psychiatric features are prominent with depression, short-lived delusions and hallucinations being most common [15]. Over $60 \%$ of patients may have persistent painful sensory features which are frequently lateralised. The majority of patients present with cerebellar features 4 to 6 months after disease onset. Myoclonus is a late feature, occurring more 6 months after onset, and chorea, tremor and dystonia are also common at this stage. Oculomotor problems and complaints of diplopia may be present in half of patients [15]. All patients develop cognitive impairment (with initial symptoms being disorientation and poor memory) and eventually dementia. Progression to death occurs on average 14 months after disease onset.

\section{Direct or indirect contact with infected individuals}

\section{Influenza}

Influenza viruses can be divided in seasonal and pandemic. The seasonal influenza A viruses (H3N2 and H1N1) cause yearly epidemics, while pandemics of influenza are the consequence of cross-species transmission, followed by adaption to humans [77]. The CNS is the most common site of extra-respiratory complication of influenza infections [77]. Febrile seizures and encephalopathy are the most frequent neurological manifestations, affecting predominantly children [137]. Other acute neurologic presentations include meningitis, encephalitis (including acute necrotising encephalopathy and acute haemorrhagic leukoencephalopathy), and an increased frequency of ischaemic stroke, all during the acute disease $[11,137]$. Influenza may also be associated with Reye's syndrome, an acute encephalopathy with 


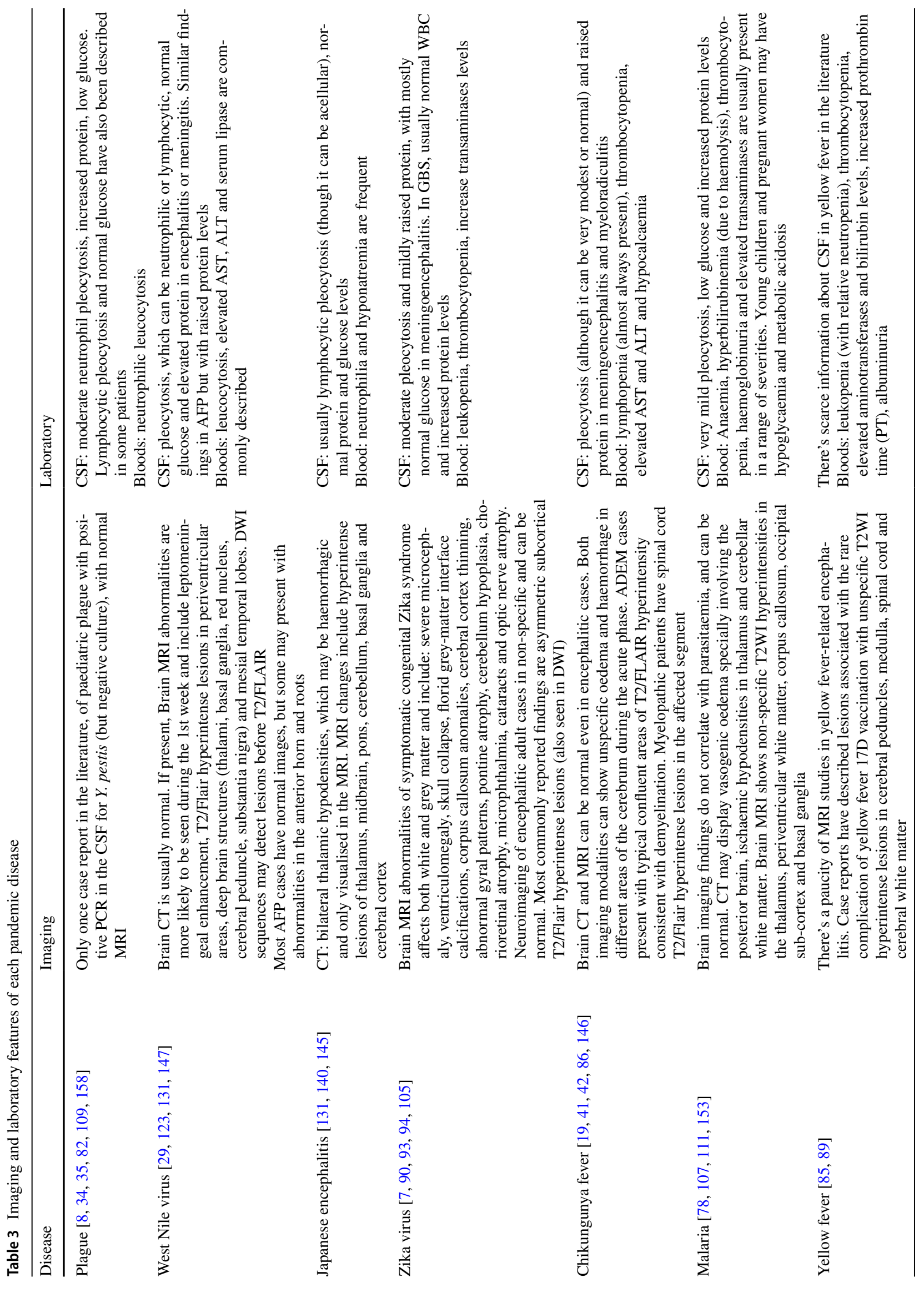




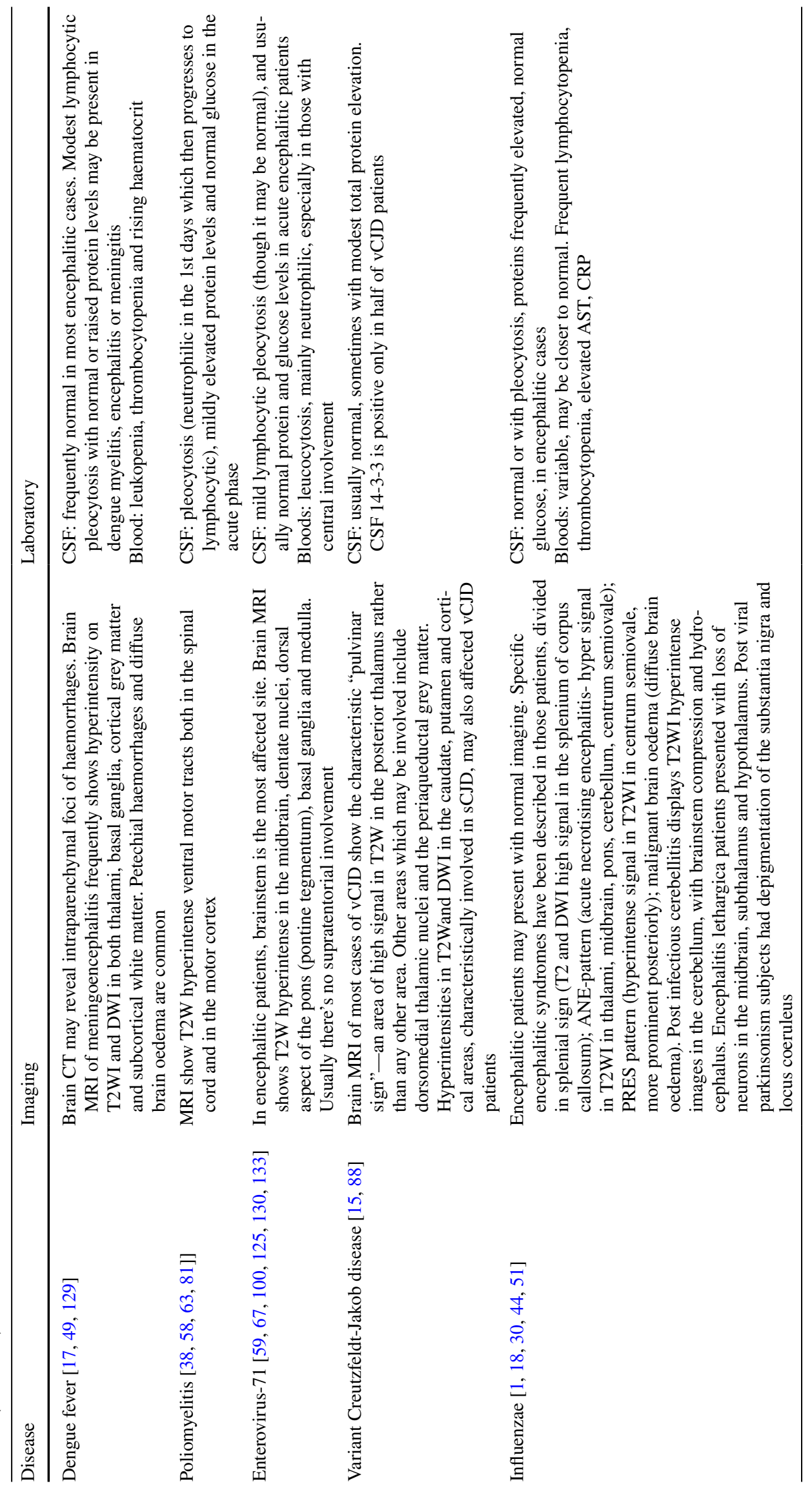




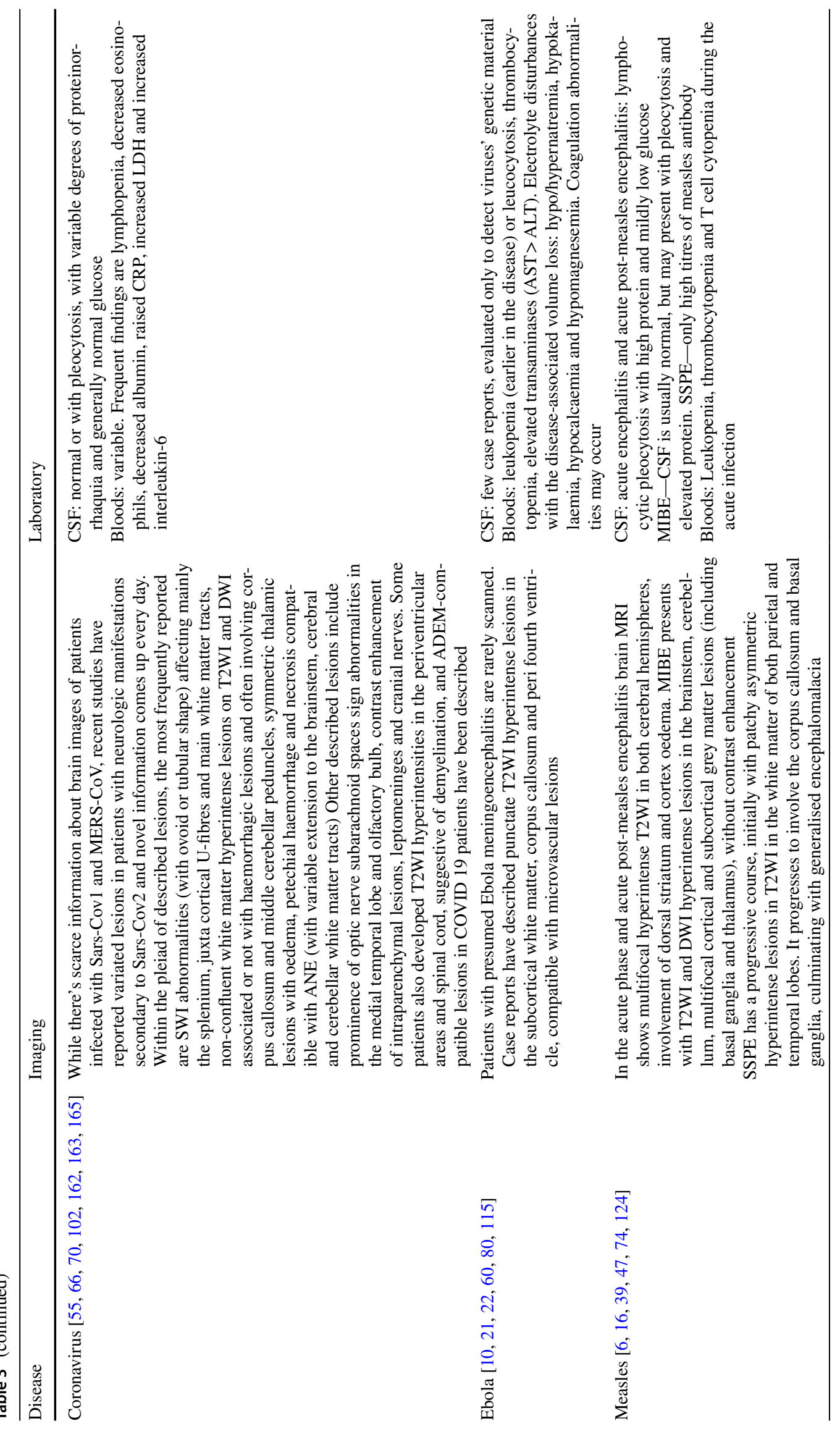




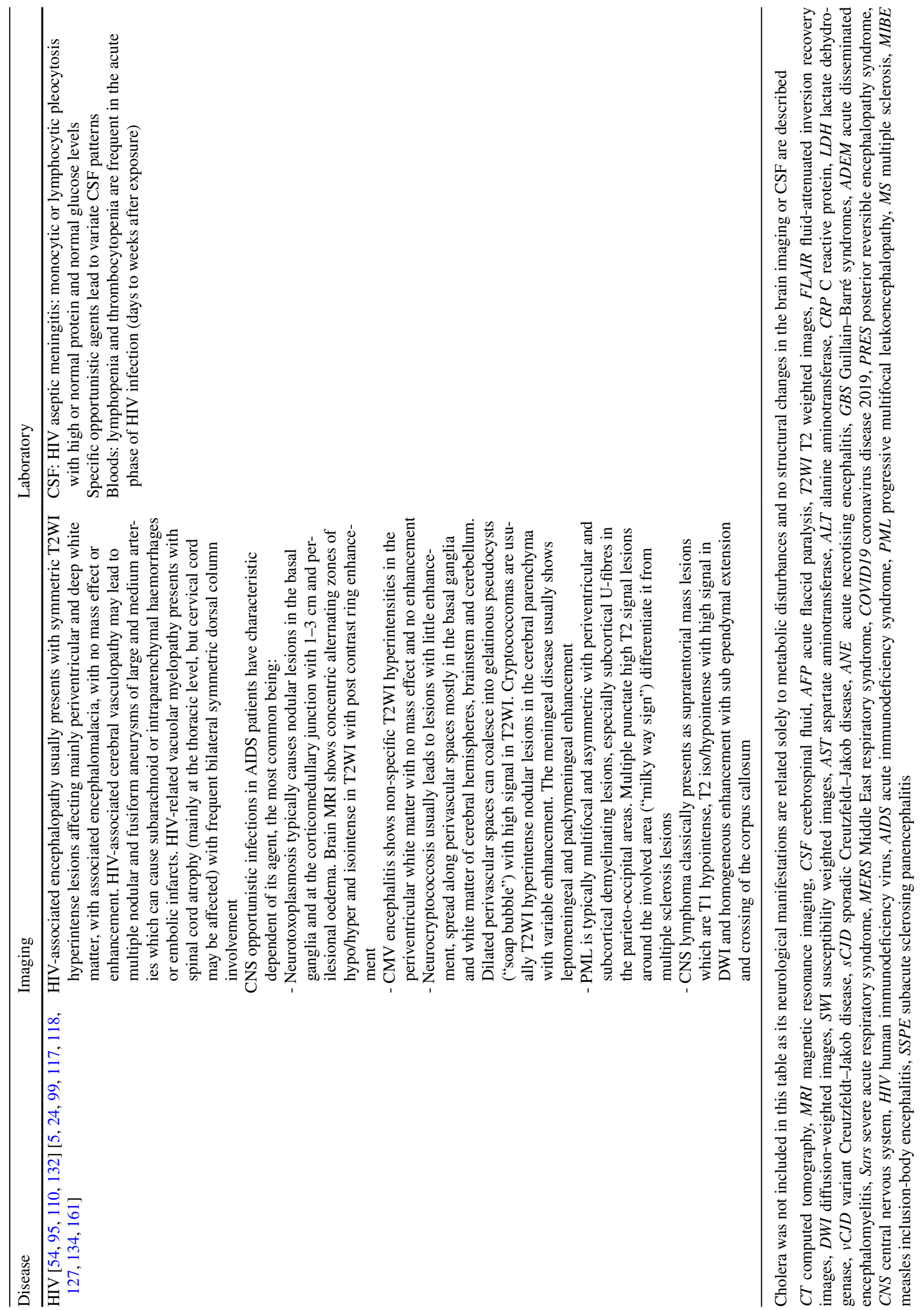


mitochondrial dysfunction and hepatic metabolic failure, triggered by drugs (especially aspirin) [121].

Late post infectious neurological complications of influenza have been extensively reported and are more frequent in adults. These include including GBS, cerebellitis, KleineLevin syndrome, myositis and transverse myelitis [137, 150]. A link between encephalitis lethargica (von Economo disease) and influenza A has been suggested with an outbreak of encephalitis lethargica cases noted after the 1918 Influenza pandemic [56]. During the acute phase, patients presented with excessive sleepiness, disorders of ocular motility, fever and movement disorders; frequently preceded by flu-like symptoms. The chronic phase typically developed 1-5 years after acute disease, but has been delayed by up to 45 years. Symptoms include Parkinsonism with psychiatric symptoms, abnormal ocular movements, speech abnormalities, spasticity and brisk reflexes; a constellation of symptoms memorably described by the neurologist Oliver Sacks in his book "Awakenings" [114]. There remains controversy whether encephalitis lethargica is caused by direct CNS invasion by the influenza virus, or represents a virus-related autoimmune phenomenon [56]. Other cases of post-encephalitic Parkinsonism not related to encephalitis lethargica have been reported after influenza infections [61].

\section{Coronaviruses}

Since the beginning of the twenty-first century three coronaviruses $(\mathrm{CoV})$ have been responsible for pandemics; severe acute respiratory syndrome (SARS-CoV1) in 2003, Middle East respiratory syndrome (MERS-CoV) in 2012 and SARSCoV2 (also known as COVID-19) in 2019. Most human coronaviruses cause only mild respiratory symptoms and four strains are endemic worldwide, responsible for up to one third of upper respiratory tract infections in immunocompetent individuals: HCoV-229E, -OC43, -NL63 and -HKU1 [32].

Coronaviruses can invade the CNS and have been associated with many neurological sequelae including demyelinating diseases [4], optic neuritis [33], and Parkinson disease [37]. HCov-OC43 was linked to a case of ADEM [160], fatal encephalitis in an immunodeficient child [91], and to a subset of Chinese children with encephalitis [75].

\section{Sars-CoV1}

The 2002-2003 pandemic affected $>8000$ people in 30 countries, $10 \%$ of whom died [71]. SARS-Cov1 was found in CSF samples and brain tissue of encephalopathic patients with symptoms including seizures [72] and optic neuritis, manifesting in the acute phase [157]. Large artery ischaemic stroke were reported in 2.4\% [141]. Neuromuscular disorders including myopathy and axonal motor neuropathy were reported among critically ill patients, later during the course of the disease. However, it is not clear whether this is a consequence of direct viral CNS infection, the host inflammatory response, and/or immunologic processes [139].

\section{MERS-CoV}

MERS has been an ongoing pandemic since initial reports in 2012 and has already affected $>2500$ people, $35 \%$ of which died [155]. In Saudi Arabia, seizures were reported during the acute phase, in $>8 \%$ of patients and confusion in $>25 \%$ [113]. ADEM, encephalitis and stroke (possibly due to vasculitis) have also been described [3]. Notably none of these conditions had MERS-CoV detected in CSF. A Korean study reported Bickerstaff's brainstem encephalitis and polyneuropathy among patients with MERS in the first few weeks of infection [64].

\section{SARS-CoV-2}

In December 2019, a new coronavirus appeared in Wuhan, China. A large current worldwide pandemic has resulted in six million recorded cases and over 1 million deaths, as of end of September 2020 [62]. Neurological complications of the disease have been reported and its mechanisms are still being scrutinised by the scientific community [36]. A retrospective Chinese study with 214 hospitalised patients described neurological features in just over one third of cohort, including dizziness, headaches and impaired consciousness [83]. A French cohort of 58 critically ill patients reported encephalopathy and corticospinal signs. Brain MRI was performed in 13 patients, 8 of whom had leptomeningeal enhancement and 2 had acute ischaemic lesions [55]. There are reports of COVID patients with rhombencephalitis [151] and meningoencephalitis [159], some with positive Sars-CoV2 in the CSF [92], most of which presented with seizures and encephalopathy. Acute haemorrhagic leukoencephalitis [108], demyelinating lesions [162], ADEM [102] and acute myelitis have also been reported [2]. Peripheral nervous system manifestations include anosmia/ageusia in over $80 \%$ of infected [73], GBS (both demyelinating and axonal) [138], Miller-Fisher syndrome (MFS) and isolated abducens palsies [48]. An increased frequency of acute cerebrovascular events among COVID patients is reported [101], at a similar frequency to previous studies of patients with sepsis [12]. This may be the consequence of a hypercoagulable state [164] related either to the viral infection or to the host response [97].

There are increasing reports of many patients suffering from a long-term syndrome lasting more than 3 months post infection which has been badged as "long COVID." Neurological-type symptoms including neurocognitive difficulties, depression and other mental health conditions, peripheral 
neuropathies and muscular weakness [46]. This is distinct from critical illness acquired weakness, and the neurocognitive sequelae described in post intensive care syndrome [9], as the majority of the patients reporting this syndrome have not been hospitalised.

\section{Ebola}

First described in 1976, Ebola has caused several outbreaks, mainly in African countries, the largest in 2014-2016. Neurological complications begin in the late stage when patients can have encephalopathy, seizures (probably due to metabolic abnormalities), meningitis and meningoencephalitis [21]. The exact prevalence of neurological complications in the acute phase is unknown. The CNS may be a reservoir for Ebola virus; it was recovered from the CSF (at higher levels than the blood) of an Ebola survivor 9 months after the patient's recovery, when it then developed meningoencephalitis and radiculitis [60]. Long-term neurological sequelae are not uncommon among survivors, with memory loss in up to $40 \%$, headaches in one third and muscle pain in $13 \%$ [128].

\section{Measles}

Until the introduction of attenuated measles vaccine, the disease killed 2-3 million people/year [154]. The mortality associated with measles decreased steadily since widespread vaccination programs were put in place in the beginning of the twenty-first century. However, since 2016, declining vaccination rates have resulted in epidemics in all WHO regions, including in previously measles-eradicated areas, like USA and Western Europe [104]. Though pneumonia is the main cause of death, severe CNS manifestations may occur. Primary measles encephalitis (PME) manifests during the exanthem due to direct CNS invasion with seizures, disturbances of consciousness and focal signs. Up to $15 \%$ of such patients die and a quarter have permanent neurological damage [16]. The most frequent CNS complication of measles is acute post measles encephalitis, which occurs 2-30 days after infection and affects around $0.1 \%$ of children after a measles infection. Another complication is measles-induced ADEM, which begins weeks or months after rash clearance $[16,47]$. Prognosis is better than with PME. Measles inclusion body encephalitis (MIBE) is another complication, in which a progressive measles virus brain infection affecting patients with impaired cellular immunity, manifesting within 1 year of the primary infection. It presents as altered consciousness, refractory seizures and focal signs. Mortality is $75 \%$ [16, 47]. Subacute sclerosing panencephalitis (SSPE) manifests 4-15 years after an acute measles infection, with a higher incidence in children who had the disease before the age of 5 [47]. SSPE is caused by persistence of a mutant measles virus after failure to completely clear the primary infection, and manifests initially as behavioural changes and cognitive decline, followed by myoclonic jerks, dyskinesias and ataxia, progressing to coma and death [16, 47]. Measles vaccination reduces SSPE incidence.

\section{HIV/AIDS}

Since the beginning of the pandemic in the 1980s, 75 million people have been infected with HIV, and 32 million have died [152]. While the introduction of combined antiretroviral therapies (cART) has decreased mortality and morbidity of acquired immunodeficiency syndrome (AIDS) and opportunistic infections (OI), the prevalence of complications associated with long-term HIV infections and its treatment have increased, particularly the neurologic ones [95]. Acute HIV infection can cause headache and neck stiffness secondary to aseptic meningitis [119].

The most common CNS OI are tuberculous meningoencephalitis, neurotoxoplasmosis, cryptococcal meningitis, cytomegalovirosis and progressive multifocal leukoencephalopathy (PML) secondary to JC virus [95]. Others include primary CNS lymphoma (associated with Epstein-Barr virus) and varicella-zoster vasculitis, with encephalopathy, cranial nerves palsies, strokes and seizures [119].

Immune reconstitution inflammatory syndrome (IRIS) may occur weeks to months after recovery from an immunodeficient state. Low CD4 before initiation of cART is the strongest predictor of IRIS. It can affect any organ and CNS-IRIS prevalence is around $1 \%$, occurring in response to dying opportunistic agents (frequently linked to Cryptococcus or PML) or as a fulminant encephalitis associated with CD8 + T cells infiltration [95].

Up to $50 \%$ of HIV patients may be affected by HIV-associated neurocognitive disorders (HAND) which range from asymptomatic to dementia [52]. HAND is a subcortical cognitive disorder and presents with psychomotor retardation, executive dysfunction, deficits of working memory, retrieval, judgment, attention and impulse control, manifesting as a long-term complication of the infection. In the cART-era the incidence of HIV-related dementia has decreased to under 5\% [95], HIV disease markers are no longer closely related to cognitive impairment [50], and patients receiving cART have a better cognitive performance than patients who are cART-naïve [52]. This indicates that the pathophysiology of cognitive impairment may be related to the inflammatory process which occurs in the presence of the virus in the CNS.

HIV infection can lead to a distal symmetric polyneuropathy, which can be related both to neurotoxic antiretrovirals and to the viral infection per se, affecting small fibres and causing numbness and painful distal limbs symptoms. Polyneuropathy affects $30-70 \%$ of HIV patients and 
immunosuppression no longer predicts its severity [103]. It may be related to neurotoxicity secondary to viral replication or to an immune reconstitution mechanism, damaging peripheral nerves and usually manifests in the chronic phase of the disease [95]. GBS (mainly demyelinating) has been associated with HIV very early in the infection [54].

$\mathrm{HIV}$ is independently associated with increased risk for stroke which may be secondary to viral effects on endothelial dysfunction, vasculopathy and hyperviscosity [103]. Protease inhibitors used as antiretrovirals may also have a negative effect on vascular endothelial function.

Vacuolar myelopathy manifests in chronic AIDS [119]. An amyotrophic lateral sclerosis-like syndrome has been reported, and may resolve resolved after initiation of cART $[95,119]$. Myopathy can occur regardless of the course of HIV infection, and is associated with direct virus lesion, inflammatory response, or ART (zidovudine) [95].

\section{Other diseases and potential threats}

Increases in global temperatures and a changing climate can lead to environmental adaptations of benefit for various disease vectors, including mosquitoes. These are the key vector for malaria, whose epidemic potential should increase in susceptible tropical countries (extending to highland areas) that had controlled the disease or be reintroduced in temperate climates that had previously eliminated it. The most severe form of malaria (and cause of 500,000 deaths per year) is cerebral [107], affecting mainly young children during the acute illness.

Yellow fever, another mosquito-borne virus, was a major threat to human health until the beginning of the twentieth century, having caused multiple epidemics and deaths in cities distant from endemic areas, in North America, the Caribbean and Europe [89]. The expansion of the disease to non-endemic areas means that susceptible non-vaccinated populations are now prone to new epidemics. The virus can rarely invade the CNS and cause encephalitis and meningitis early in the course of infection. Encephalopathy is also common in the context of hepatic failure of severe forms of the disease. Though extremely rare, yellow fever vaccine-associated neurotropic disease is reported, causing encephalitis, GBS and ADEM [89].

The mosquito-borne dengue virus has expanded from a sporadic disease affecting 9 countries in the 1970s to being endemic in over 100 countries; half of the world is now at risk. Neurological complications can occur at any stage. Dengue encephalopathy is the most common and involves impaired consciousness in the context of shock, liver failure and electrolyte disturbances in the first 10 days of the disease. Meningitis and encephalitis due to CNS invasion of the virus are also possible, though rare, and patients present with decreased level of consciousness, headache, dizziness, seizures and focal signs, also in the acute phase. Post-dengue immune-mediated complications include GBS, transverse myelitis, ADEM, mononeuropathies of cranial nerves, optic neuropathy, muscle dysfunction and intracranial haemorrhages during the convalescence stage [17].

War, conflicts and natural disasters can facilitate the spread of diseases like cholera. Cholera has caused seven pandemics in the last two centuries. Electrolyte disturbances and hypoglycaemia (mainly in children) secondary to severe diarrhoea and acute dehydration can lead to symptomatic seizures [23]. Concurrent outbreaks of cholera and peripheral neuropathies have been described among undernourished displaced populations, in the subacute phase of the disease [112].

The recent decrease in coverage of MMR (measles, mumps and rubella) vaccine in some areas has also led to an increase of cases of rubella and mumps. Mumps can cause aseptic meningitis and encephalitis in the early days of the disease and ADEM as a late post infectious complication [6]. The major neurological manifestation of rubella is the congenital rubella syndrome (CRS) in foetuses whose mothers are infected during pregnancy. CRS includes causes encephalopathy, microcephaly and sensorineural hearing loss. Encephalitis has also been reported during the exantematic phase [6].

Smallpox was a cause of massive epidemics until its eradication in the 1980s by global immunisation programs. Since most of people living today are not vaccinated against it and the viable variola virus is still kept in two maximum security laboratories [87], it is feared that it could be used in bioterrorist attacks. Neurological complications of smallpox were uncommon and have been poorly studied, but descriptions are compatible with demyelinating/inflammatory encephalomyelitis, 5 to 16 days after the acute disease [13]. Post-vaccination encephalomyelitis has also been described, mainly in young children [13].

\section{Conclusion: preparing for the future}

Pandemics and epidemics have been present for thousands of years, and have played a pivotal role in history. Much of previous focus has been on the acute illnesses themselves, with relatively little attention paid to the social, human and economic consequences of neurological sequelae. However, it is these sequelae that often lead to significant amounts of mortality and long-term morbidity.

Under-recognition of neurological manifestations means that few studies have been conducted in previous pandemics to understand, treat and prevent neurological complications, and so the burden of secondary complications is even greater. With the recent developments in imaging, new 
information about the presentation of CNS diseases is available and can assist in the proper diagnosis of neurologic manifestations of infectious diseases. However, even in developed countries, diagnostic tests are limited and treatments are often inadequate or non-existent, with significant long-term economic and healthcare consequences. Therefore, it is reasonable to expect that in low and middle-income countries with poorer access to diagnostic tests and treatments, the neurological involvement by these diseases will have a greater economic impact. Potentially limiting future human capital by leaving long-term motor and cognitive impairments.

This urgent need to pay more attention to the short- and longer term sequelae of pandemics has been brought into sharp focus with COVID-19 where there have been numerous reports of short-term sequelae and a growing appreciation of longer term problems. There is a growing recognition of the need to work globally with international collaborations being formed to better understand the neurological consequences of COVID-19 [53]. These include (but are not exclusive to) the CoroNerve Study Group [143], European Academy of Neurology's EAN Neuro-COVID Registry Consortium (ENERGY) [98], and the Global Consortium Study of Neurological Dysfunction in COVID-19 (GCSNeuroCOVID) [40].

However, it is also important to learn from previous pandemics to understand what to expect and plan responses to improve the outcomes. This knowledge of what has occurred the past is useful to highlight symptoms and signs to be vigilant for ensuring such sequelae are not missed. For example, encephalitis lethargica and post-encephalitic parkinsonism have been seen after viral infections, most notably the 1918-19 influenza pandemic [43]. Indeed, a case of parkinsonism in a patient post COVID-19 has been described, including a reduction of ${ }^{18} \mathrm{~F}$-fluorodopa uptake bilaterally in the putamina [25], In the months to years following this pandemic it would be important to continue to look for such patients.

As new infections continue to emerge, new pandemics will certainly happen. Despite advances in the treatment of infectious diseases in the last century, those affecting the nervous system are still challenging. An improved understanding of the pathophysiology of neurologic damage and recognising its possible manifestations is fundamental to develop new treatments and management strategies.

Neurological involvement in pandemics and epidemics is common and can cause devastating consequences amongst affected populations. There is an urgent need for better address this issue in pandemics, including the current SARS-CoV-2 outbreak.

Acknowledgements DW was supported by an Academic Clinical Fellowship. DKM was supported by the NIHR through the NIHR
Cambridge Biomedical Research Centre grant and a Senior Investigator Award. VFJN was supported by an Academy of Medical Sciences/ The Health Foundation Fellowship.

Author contributions FV and VFJN conceived the idea. FV performed the literature review and initial draft. All authors contributed substantially to the writing of the manuscript.

Funding DW was supported by an Academic Clinical Fellowship. DKM was supported by the NIHR through the NIHR Cambridge Biomedical Research Centre grant and a Senior Investigator Award. VFJN was supported by an Academy of Medical Sciences/The Health Foundation Fellowship. No funding source had any role in the writing of this manuscript and decision to submit for publication.

\section{Compliance with ethical standards}

Conflicts of interest On behalf of all authors, the corresponding author states that there is no conflict of interest.

Open Access This article is licensed under a Creative Commons Attribution 4.0 International License, which permits use, sharing, adaptation, distribution and reproduction in any medium or format, as long as you give appropriate credit to the original author(s) and the source, provide a link to the Creative Commons licence, and indicate if changes were made. The images or other third party material in this article are included in the article's Creative Commons licence, unless indicated otherwise in a credit line to the material. If material is not included in the article's Creative Commons licence and your intended use is not permitted by statutory regulation or exceeds the permitted use, you will need to obtain permission directly from the copyright holder. To view a copy of this licence, visit http://creativecommons.org/licenses/by/4.0/.

\section{References}

1. Akins PT, Belko J, Uyeki TM, Axelrod Y, Lee KK, Silverthorn J (2010) H1N1 encephalitis with malignant edema and review of neurologic complications from influenza. Neurocrit Care 13:396-406

2. AlKetbi R, AlNuaimi D, AlMulla M, AlTalai N, Samir M, Kumar N (2020) Acute myelitis as a neurological complication of Covid-19: a case report and MRI findings. Radiol Case Rep 15(9):1591-1595

3. Arabi YM, Harthi A, Hussein J, Bouchama A, Johani S, Hajeer AH, Saeed BT, Wahbi A, Saedy A, AlDabbagh T, Okaili R, Sadat M, Balkhy H (2015) Severe neurologic syndrome associated with Middle East respiratory syndrome corona virus (MERS-CoV). Infection 43:495-501

4. Arbour N, Day R, Newcombe J, Talbot PJ (2000) Neuroinvasion by human respiratory coronaviruses. J Virol 74:8913-8921

5. Bag AK, Curé JK, Chapman PR, Roberson GH, Shah R (2010) JC virus infection of the brain. Am J Neuroradiol 31:1564-1576

6. Bale JF Jr (2014) Measles, mumps, rubella, and human parvovirus B19 infections and neurologic disease. Handb Clin Neurol 121:1345-1353

7. Baud D, Gubler DJ, Schaub B, Lanteri MC, Musso D (2017) An update on Zika virus infection. Lancet 390:2099-2109

8. Becker TM, Poland JD, Quan TJ, White ME, Mann JM, Barnes AM (1987) Plague meningitis-a retrospective analysis of cases reported in the United States, 1970-1979. West J Med 147:554-557 
9. Biehl M, Sese D (2020) Post-intensive care syndrome and COVID-19 - Implications post pandemic. Clevel Clin J Med. https://doi.org/10.3949/ccjm.87a.ccc055

10. Billioux BJ, Smith B, Nath A (2016) Neurological complications of Ebola virus infection. Neurotherapeutics 13:461-470

11. Boehme AK, Luna J, Kulick ER, Kamel H, Elkind MSV (2018) Influenza-like illness as a trigger for ischemic stroke. Ann Clin Transl Neurol 5:456-463

12. Boehme AK, Ranawat P, Luna J, Kamel H, Elkind MS (2017) Risk of acute stroke after hospitalization for sepsis: a case-crossover study. Stroke 48:574-580

13. Booss J, Davis LE (2003) Smallpox and smallpox vaccination: neurological implications. Neurology 60:1241-1245

14. Boulanger LL, Ettestad P, Fogarty JD, Dennis DT, Romig D, Mertz G (2004) Gentamicin and tetracyclines for the treatment of human plague: review of 75 cases in New Mexico, 1985-1999. Clin Infect Dis 38:663-669

15. Brandel JP, Knight R (2018) Variant Creutzfeldt-Jakob disease. Handb Clin Neurol 153:191-205

16. Buchanan R, Bonthius DJ (2012) Measles virus and associated central nervous system sequelae. Semin Pediatr Neurol 19:107-114

17. Carod-Artal FJ, Wichmann O, Farrar J, Gascón J (2013) Neurological complications of dengue virus infection. Lancet Neurol 12:906-919

18. Casals J, Elizan TS, Yahr MD (1998) Postencephalitic parkinsonism-a review. J Neural Transm (Vienna) 105:645-676

19. Cerny T, Schwarz M, Schwarz U, Lemant J, Gérardin P, Keller E (2017) The range of neurological complications in Chikungunya fever. Neurocrit Care 27:447-457

20. Chang LY, Huang LM, Gau SS, Wu YY, Hsia SH, Fan TY, Lin KL, Huang YC, Lu CY, Lin TY (2007) Neurodevelopment and cognition in children after enterovirus 71 infection. N Engl J Med 356:1226-1234

21. Chertow DS, Kleine C, Edwards JK, Scaini R, Giuliani R, Sprecher A (2014) Ebola virus disease in West Africa — clinical manifestations and management. N Engl J Med 371:2054-2057

22. Chertow DS, Nath A, Suffredini AF, Danner RL, Reich DS, Bishop RJ, Childs RW, Arai AE, Palmore TN, Lane HC, Fauci AS, Davey RT (2016) Severe meningoencephalitis in a case of Ebola virus disease: a case report. Ann Intern Med 165:301-304

23. Clemens JD, Nair GB, Ahmed T, Qadri F, Holmgren J (2017) Cholera. The Lancet 390:1539-1549

24. Clifford DB, Ances BM (2013) HIV-associated neurocognitive disorder. Lancet Infect Dis 13:976-986

25. Cohen ME, Eichel R, Steiner-Birmanns B, Janah A, Ioshpa M, Bar-Shalom R, Paul JJ, Gaber H, Skrahina V, Bornstein NM, Yahalom G (2020) A case of probable Parkinson's disease after SARS-CoV-2 infection. Lancet Neurol 19:804-805

26. Collinge J, Sidle KC, Meads J, Ironside J, Hill AF (1996) Molecular analysis of prion strain variation and the aetiology of "new variant' CJD. Nature 383:685-690

27. Cousens SN, Vynnycky E, Zeidler M, Will RG, Smith PG (1997) Predicting the CJD epidemic in humans. Nature 385:197-198

28. Dando SJ, Mackay-Sim A, Norton R, Currie BJ, St. John JA, Ekberg JAK, Batzloff M, Ulett GC, Beacham IR (2014) Pathogens penetrating the central nervous system: infection pathways and the cellular and molecular mechanisms of invasion. Clin Microbiol Rev 27:691-726

29. Davis LE, DeBiasi R, Goade DE, Haaland KY, Harrington JA, Harnar JB, Pergam SA, King MK, DeMasters BK, Tyler KL (2006) West Nile virus neuroinvasive disease. Ann Neurol 60:286-300

30. Davis LE, Koster F, Cawthon A (2014) Neurologic aspects of influenza viruses. Handb Clin Neurol 123:619-645
31. de Araújo TVB, Rodrigues LC, de Alencar Ximenes RA, de Barros M-F, Montarroyos UR, de Melo APL, Valongueiro S, de Albuquerque M, Souza WV, Braga C, Filho SPB, Cordeiro MT, Vazquez E, Cruz DCS, D, Henriques CMP, Bezerra LCA, da Silva Castanha PM, Dhalia R, Marques-Júnior ETA, Martelli CMT, (2016) Association between Zika virus infection and microcephaly in Brazil, January to May, 2016: preliminary report of a case-control study. Lancet Infect Dis 16:1356-1363

32. Desforges M, Le Coupanec A, Dubeau P, Bourgouin A, Lajoie L, Dubé M, Talbot PJ (2020) Human coronaviruses and other respiratory viruses: underestimated opportunistic pathogens of the central nervous system? Viruses 12:14

33. Dessau RB, Lisby G, Frederiksen JL (1999) Coronaviruses in spinal fluid of patients with acute monosymptomatic optic neuritis. Acta Neurol Scand 100:88-91

34. Drummond WK, Nelson CA, Fowler J, Epson EE, Mead PS, Lawaczeck EW (2014) Plague in a pediatric patient: case report and use of polymerase chain reaction as a diagnostic aid. J Pediatric Infect Dis Soc 3:e38-e41

35. Dunning J, Morgan D, Walsh A (2017) Plague: interim guidance for clinicians in England managing suspected cases. Public Health England (PHE). Retrieved from https://assets.publi shing.service.gov.uk/government/uploads/system/uploads/attac hment_data/file/743275/Plague_clinical_guidance.pdf. Accessed 3 Sept 2020

36. Ellul MA, Benjamin L, Singh B, Lant S, Michael BD, Easton A, Kneen R, Defres S, Sejvar J, Solomon T (2020) Neurological associations of COVID-19. Lancet Neurol 19:767-783

37. Fazzini E, Fleming J, Fahn S (1992) Cerebrospinal fluid antibodies to coronavirus in patients with Parkinson's disease. Mov Disord 7:153-158

38. Ferraz-Filho JR, dos Santos TU, de Oliveira EP, Souza AS (2010) MRI findings in an infant with vaccine-associated paralytic poliomyelitis. Pediatr Radiol 40(Suppl 1):S138-140

39. Fisher DL, Defres S, Solomon T (2015) Measles-induced encephalitis. QJM 108:177-182

40. Frontera J, Mainali S, Fink EL, Robertson CL, Schober M, Ziai W, Menon D, Kochanek PM, Suarez JI, Helbok R, McNett M, Chou SH (2020) Global consortium study of neurological dysfunction in COVID-19 (GCS-NeuroCOVID): study design and rationale. Neurocrit Care 33:25-34

41. Ganesan VK, Duan B, Reid SP (2017) Chikungunya virus: pathophysiology, mechanism, and modeling. Viruses 9:368

42. Gérardin P, Couderc T, Bintner M, Tournebize P, Renouil M, Lémant J, Boisson V, Borgherini G, Staikowsky F, Schramm F, Lecuit M,Michault A, Encephalchik Study Group (2016) Chikungunya virus-associated encephalitis: a cohort study on La Réunion Island, 2005-2009. Neurology 86(1):94-102. https:// doi.org/10.1212/WNL.0000000000002234

43. Giordano A, Schwarz G, Cacciaguerra L, Esposito F, Filippi M (2020) COVID-19: can we learn from encephalitis lethargica? Lancet Neurol 19:570

44. Goenka A, Michael BD, Ledger E, Hart IJ, Absoud M, Chow G, Lilleker J, Lunn M, McKee D, Peake D, Pysden K, Roberts M, Carrol ED, Lim M, Avula S, Solomon T, Kneen R (2014) Neurological manifestations of influenza infection in children and adults: results of a National British Surveillance Study. Clin Infect Dis 58:775-784

45. Gofton TE, Young GB (2012) Sepsis-associated encephalopathy. Nat Rev Neurol 8:557-566

46. Greenhalgh T, Knight M, A'Court C, Buxton M, Husain L (2020) Management of post-acute covid-19 in primary care. BMJ 370:m3026

47. Griffin DE (2014) Measles virus and the nervous system. Handb Clin Neurol 123:577-590 
48. Gutiérrez-Ortiz C, Méndez A, Rodrigo-Rey S, San Pedro-Murillo E, Bermejo-Guerrero L, Gordo-Mañas R, de Aragón-Gómez F, Benito-León J (2020) Miller fisher syndrome and polyneuritis cranialis in COVID-19. Neurology. https://doi.org/10.1212/ WNL.0000000000009619

49. Guzman MG, Harris E (2015) Dengue. Lancet 385:453-465

50. Haddow LJ, Laverick R, Daskalopoulou M, McDonnell J, Lampe FC, Gilson R, Speakman A, Antinori A, Balestra P, Bruun T, Gerstoft J, Nielsen L, Vassilenko A, Collins S, Rodger AJ (2018) Multicenter European prevalence study of neurocognitive impairment and associated factors in HIV positive patients. AIDS Behav 22:1573-1583

51. Hayase Y, Tobita K (1997) Probable post-influenza cerebellitis. Intern Med 36:747-749

52. Heaton RK, Clifford DB, Franklin DR Jr, Woods SP, Ake C, Vaida F, Ellis RJ, Letendre SL, Marcotte TD, Atkinson JH, Rivera-Mindt M, Vigil OR, Taylor MJ, Collier AC, Marra CM, Gelman BB, McArthur JC, Morgello S, Simpson DM, McCutchan JA, Abramson I, Gamst A, Fennema-Notestine C, Jernigan TL, Wong J, Grant I (2010) HIV-associated neurocognitive disorders persist in the era of potent antiretroviral therapy: CHARTER study. Neurology 75:2087-2096

53. Helbok R, Chou SH-Y, Beghi E, Mainali S, Frontera J, Robertson C, Fink E, Schober M, Moro E, McNett M, Bassetti CL (2020) NeuroCOVID: it's time to join forces globally. Lancet Neurol 19:805-806

54. Hellmuth J, Fletcher JL, Valcour V, Kroon E, Ananworanich J, Intasan J, Lerdlum S, Narvid J, Pothisri M, Allen I, Krebs SJ, Slike B, Prueksakaew P, Jagodzinski LL, Puttamaswin S, Phanuphak N, Spudich S (2016) Neurologic signs and symptoms frequently manifest in acute HIV infection. Neurology 87:148-154

55. Helms J, Kremer S, Merdji H, Clere-Jehl R, Schenck M, Kummerlen C, Collange O, Boulay C, Fafi-Kremer S, Ohana M, Anheim M, Meziani F (2020) Neurologic features in severe SARS-CoV-2 Infection. N Engl J Med 382(23):2268-2270. https ://doi.org/10.1056/NEJMc2008597

56. Hoffman LA, Vilensky JA (2017) Encephalitis lethargica: 100 years after the epidemic. Brain 140:2246-2251

57. Hotchkiss RS, Moldawer LL, Opal SM, Reinhart K, Turnbull IR, Vincent JL (2016) Sepsis and septic shock. Nat Rev Dis Primers 2:16045

58. Howard RS (2005) Poliomyelitis and the postpolio syndrome. BMJ 330:1314-1318

59. Huang CC, Liu CC, Chang YC, Chen CY, Wang ST, Yeh TF (1999) Neurologic complications in children with enterovirus 71 infection. N Engl J Med 341:936-942

60. Jacobs M, Rodger A, Bell DJ, Bhagani S, Cropley I, Filipe A, Gifford RJ, Hopkins S, Hughes J, Jabeen F, Johannessen I, Karageorgopoulos D, Lackenby A, Lester R, Liu RSN, MacConnachie A, Mahungu T, Martin D, Marshall N, Mepham S, Orton R, Palmarini M, Patel M, Perry C, Peters SE, Porter D, Ritchie D, Ritchie ND, Seaton RA, Sreenu VB, Templeton K, Warren S, Wilkie GS, Zambon M, Gopal R, Thomson EC (2016) Late Ebola virus relapse causing meningoencephalitis: a case report. Lancet 388:498-503

61. Jang H, Boltz DA, Webster RG, Smeyne RJ (2009) Viral parkinsonism. Biochim Biophys Acta 1792:714-721

62. Coronavirus Resource Center - John Hopkins University and Medicine (2020) COVID-19 dashboard by the center for systems science and engineering (CSSE) at Johns Hopkins University. Retrieved from https://coronavirus.jhu.edu/map.html. Accessed 2 Oct 2020

63. Kidd D, Williams AJ, Howard RS (1996) Poliomyelitis. Postgrad Med J 72:641-647

64. Kim JE, Heo JH, Kim HO, Song SH, Park SS, Park TH, Ahn JY, Kim MK, Choi JP (2017) Neurological complications during treatment of middle east respiratory syndrome. J Clin Neurol $13: 227-233$

65. Klein RS, Garber C, Howard N (2017) Infectious immunity in the central nervous system and brain function. Nat Immunol 18:132-141

66. Klironomos S, Tzortzakakis A, Kits A, Öhberg C, Kollia E, Ahoromazdae A, Almqvist H, Aspelin A, Martin H, Ouellette R, Al-Saadi J, Hasselberg M, Haghgou M, Pedersen M, Petersson S, Finnsson J, Lundberg J, Falk Delgado A, Granberg T (2020) Nervous system involvement in COVID-19: results from a retrospective consecutive neuroimaging cohort. Radiology. https:// doi.org/10.1148/radiol.2020202791

67. Komatsu H, Shimizu Y, Takeuchi Y, Ishiko H, Takada H (1999) Outbreak of severe neurologic involvement associated with Enterovirus 71 infection. Pediatr Neurol 20:17-23

68. Koyuncu OO, Hogue IB, Enquist LW (2013) Virus infections in the nervous system. Cell Host Microbe 13:379-393

69. Kramer LD, Li J, Shi PY (2007) West Nile virus. Lancet Neurol 6:171-181

70. Kremer S, Lersy F, de Sèze J, Ferré JC, Maamar A, Carsin-Nicol B, Collange O, Bonneville F, Adam G, Martin-Blondel G, Rafiq M, Geeraerts T, Delamarre L, Grand S, Krainik A, Caillard S, Marc Constans J, Metanbou S, Heintz A, Helms J, Schenck M, Lefèbvre N, Boutet C, Fabre X, Forestier G, de Beaurepaire I, Bornet G, Lacalm A, Oesterlé H, Bolognini F, Messie J, Hmeydia G, Benzakoun J, Oppenheim C, Bapst B, Megdiche I, HenriFeugeas MC, Khalil A, Gaudemer A, Jager L, Nesser P, Talla Mba Y, Hemmert C, Feuerstein P, Sebag N, Carré S, Alleg M, Lecocq C, Schmitt E, Anxionnat R, Zhu F, Comby PO, Ricolfi F, Thouant P, Desal H, Boulouis G, Berge J, Kazémi A, Pyatigorskaya N, Lecler A, Saleme S, Edjlali-Goujon M, Kerleroux B, Zorn PE, Mathieu M, Baloglu S, Ardellier FD, Willaume T, Brisset JC, Boulay C, Mutschler V, Hansmann Y, Mertes PM, Schneider F, Fafi-Kremer S, Ohana M, Meziani F, David JS, Meyer N, Anheim M, Cotton F (2020) Brain MRI findings in severe COVID-19: a retrospective observational study. Radiology. https://doi.org/10.1148/radiol.2020202222

71. Ksiazek TG, Erdman D, Goldsmith CS, Zaki SR, Peret T, Emery S, Tong S, Urbani C, Comer JA, Lim W, Rollin PE, Dowell SF, Ling AE, Humphrey CD, Shieh WJ, Guarner J, Paddock CD, Rota P, Fields B, DeRisi J, Yang JY, Cox N, Hughes JM, LeDuc JW, Bellini WJ, Anderson LJ (2003) A novel coronavirus associated with severe acute respiratory syndrome. N Engl J Med 348:1953-1966

72. Lau KK, Yu WC, Chu CM, Lau ST, Sheng B, Yuen KY (2004) Possible central nervous system infection by SARS coronavirus. Emerg Infect Dis 10:342-344

73. Lechien JR, Chiesa-Estomba CM, De Siati DR, Horoi M, Le Bon SD, Rodriguez A, Dequanter D, Blecic S, El Afia F, Distinguin L, Chekkoury-Idrissi Y, Hans S, Delgado IL, Calvo-Henriquez C, Lavigne P, Falanga C, Barillari MR, Cammaroto G, Khalife M, Leich P, Souchay C, Rossi C, Journe F, Hsieh J, Edjlali M, Carlier R, Ris L, Lovato A, De Filippis C, Coppee F, Fakhry N, Ayad T, Saussez S (2020) Olfactory and gustatory dysfunctions as a clinical presentation of mild-to-moderate forms of the coronavirus disease (COVID-19): a multicenter European study. Eur Arch Otorhinolaryngol 277:2251-2261

74. Lee KY, Cho WH, Kim SH, Kim HD, Kim IO (2003) Acute encephalitis associated with measles: MRI features. Neuroradiology 45:100-106

75. Li Y, Li H, Fan R, Wen B, Zhang J, Cao X, Wang C, Song Z, Li S, Li X, Lv X, Qu X, Huang R, Liu W (2016) Coronavirus infections in the central nervous system and respiratory tract show distinct features in hospitalized children. Intervirology 59:163-169 
76. Lo JK, Robinson LR (2018) Post-polio syndrome and the late effects of poliomyelitis: Part 2. treatment, management, and prognosis. Muscle Nerve 58:760-769

77. Ludlow M, Kortekaas J, Herden C, Hoffmann B, Tappe D, Trebst C, Griffin DE, Brindle HE, Solomon T, Brown AS, van Riel D, Wolthers KC, Pajkrt D, Wohlsein P, Martina BEE, Baumgärtner W, Verjans GM, Osterhaus ADME (2016) Neurotropic virus infections as the cause of immediate and delayed neuropathology. Acta Neuropathol 131:159-184

78. Luzolo AL, Ngoyi DM (2019) Cerebral malaria. Brain Res Bull 145:53-58

79. Madhav N, Oppenheim B, Gallivan M, Mulembakani P, Rubin E, Wolfe N (2017) Pandemics: Risks, Impacts, and Mitigation. In: Jamison DT, Gelband H, Horton S, Jha P, Laxminarayan R, Mock CN, Nugent R (eds) Disease control priorities: improving health and reducing poverty. The International Bank for Reconstruction and Development/The World Bank@ 2018 International Bank for Reconstruction and Development/The World Bank., Washington (DC)

80. Malvy D, McElroy AK, de Clerck H, Günther S, van Griensven J (2019) Ebola virus disease. Lancet 393:936-948

81. Malzberg MS, Rogg JM, Tate CA, Zayas V, Easton JD (1993) Poliomyelitis: hyperintensity of the anterior horn cells on MR images of the spinal cord. AJR Am J Roentgenol 161:863-865

82. Mann JM, Shandler L, Cushing AH (1982) Pediatric plague. Pediatrics 69:762-767

83. Mao L, Jin H, Wang M, Hu Y, Chen S, He Q, Chang J, Hong C, Zhou Y, Wang D, Miao X, Li Y, Hu B (2020) Neurologic manifestations of hospitalized patients with coronavirus disease 2019 in Wuhan, China. JAMA Neurol 77:683

84. McGavern DB, Kang SS (2011) Illuminating viral infections in the nervous system. Nat Rev Immunol 11:318-329

85. McMahon AW, Eidex RB, Marfin AA, Russell M, Sejvar JJ, Markoff L, Hayes EB, Chen RT, Ball R, Braun MM, Cetron M (2007) Neurologic disease associated with 17D-204 yellow fever vaccination: a report of 15 cases. Vaccine 25:1727-1734

86. Mehta R, Gerardin P, de Brito CAA, Soares CN, Ferreira MLB, Solomon T (2018) The neurological complications of chikungunya virus: a systematic review. Rev Med Virol 28:e1978

87. Meyer H, Ehmann R, Smith GL (2020) Smallpox in the posteradication era. Viruses 12:138

88. Molloy S, O'Laoide R, Brett F, Farrell M (2000) The "Pulvinar" sign in variant Creutzfeldt-Jakob disease. AJR Am J Roentgenol 175:555-556

89. Monath TP, Vasconcelos PF (2015) Yellow fever. J Clin Virol 64:160-173

90. Moore CA, Staples JE, Dobyns WB, Pessoa A, Ventura CV, Fonseca EBd, Ribeiro EM, Ventura LO, Neto NN, Arena JF, Rasmussen SA (2017) Characterizing the pattern of anomalies in congenital Zika syndrome for pediatric clinicians. JAMA Pediatrics 171:288-295

91. Morfopoulou S, Brown JR, Davies EG, Anderson G, Virasami A, Qasim W, Chong WK, Hubank M, Plagnol V, Desforges M, Jacques TS, Talbot PJ, Breuer J (2016) Human coronavirus OC43 associated with fatal encephalitis. N Engl J Med 375:497-498

92. Moriguchi T, Harii N, Goto J, Harada D, Sugawara H, Takamino J, Ueno M, Sakata H, Kondo K, Myose N, Nakao A, Takeda M, Haro H, Inoue O, Suzuki-Inoue K, Kubokawa K, Ogihara S, Sasaki T, Kinouchi H, Kojin H, Ito M, Onishi H, Shimizu T, Sasaki Y, Enomoto N, Ishihara H, Furuya S, Yamamoto T, Shimada S (2020) A first Case of Meningitis/Encephalitis associated with SARS-Coronavirus-2. Int J Infect Dis 94:55-58

93. Musso D, Gubler DJ (2016) Zika virus. Clin Microbiol Rev 29:487-524

94. Musso D, Ko AI, Baud D (2019) Zika virus infection—after the pandemic. N Engl J Med 381:1444-1457
95. Nath A (2015) Neurologic complications of human immunodeficiency virus infection. Continuum (Minneap Minn) 21:1557-1576

96. Nathanson N, Kew OM (2010) From emergence to eradication: the epidemiology of poliomyelitis deconstructed. Am J Epidemiol 172:1213-1229

97. Needham EJ, Chou SHY, Coles AJ, Menon DK (2020) Neurological implications of COVID-19 infections. Neurocrit Care 32:667-671

98. European Academy of Neurology (EAN) (2020) EANcore COVID-19. Retrieved from https://www.ean.org/ean/eancorecovid-19. Accessed 2 Oct 2020

99. Offiah CE, Naseer A (2016) Spectrum of imaging appearances of intracranial cryptococcal infection in HIV/AIDS patients in the anti-retroviral therapy era. Clin Radiol 71:9-17

100. Ooi MH, Wong SC, Lewthwaite P, Cardosa MJ, Solomon T (2010) Clinical features, diagnosis, and management of enterovirus 71. Lancet Neurol 9:1097-1105

101. Oxley TJ, Mocco J, Majidi S, Kellner CP, Shoirah H, Singh IP, De Leacy RA, Shigematsu T, Ladner TR, Yaeger KA, Skliut M, Weinberger J, Dangayach NS, Bederson JB, Tuhrim S, Fifi JT (2020) Large-vessel stroke as a presenting feature of Covid-19 in the young. N Engl J Med 382:e60

102. Parsons T, Banks S, Bae C, Gelber J, Alahmadi H, Tichauer M (2020) COVID-19-associated acute disseminated encephalomyelitis (ADEM). J Neurol 1-4

103. Patel PB, Spudich SS (2018) Global health neurology: HIV/ AIDS. Semin Neurol 38:238-246

104. Paules CI, Marston HD, Fauci AS (2019) Measles in 2019going backward. N Engl J Med 380:2185-2187

105. Petersen LR, Jamieson DJ, Powers AM, Honein MA (2016) Zika virus. N Engl J Med 374:1552-1563

106. Pohl D, Alper G, Van Haren K, Kornberg AJ, Lucchinetti CF, Tenembaum S, Belman AL (2016) Acute disseminated encephalomyelitis. Updat Inflamm CNS Syndr 87:S38-S45

107. Postels DG, Birbeck GL (2013) Cerebral malaria. Handb Clin Neurol 114:91-102

108. Poyiadji N, Shahin G, Noujaim D, Stone M, Patel S, Griffith B (2020) COVID-19-associated Acute hemorrhagic necrotizing encephalopathy: CT and MRI features. Radiology 201187

109. Prentice MB, Rahalison L (2007) Plague. Lancet 369:1196-1207

110. Ragin AB, Wu Y, Gao Y, Keating S, Du H, Sammet C, Kettering CS, Epstein LG (2015) Brain alterations within the first 100 days of HIV infection. Ann Clin Transl Neurol 2:12-21

111. Rasheed A, Saeed S, Khan SA (2009) Clinical and laboratory findings in acute malaria caused by various plasmodium species. J Pak Med Assoc 59:220-223

112. Rosewell A, Clark G, Mabong P, Ropa B, Posanai E, Man NW, Dutta SR, Wickramasinghe W, Qi L, Ng JC, Mola G, Zwi AB, MacIntyre CR (2013) Concurrent outbreaks of cholera and peripheral neuropathy associated with high mortality among persons internally displaced by a volcanic eruption. PLoS ONE 8:e72566

113. Saad M, Omrani AS, Baig K, Bahloul A, Elzein F, Matin MA, Selim MA, Al Mutairi M, Al Nakhli D, Al Aidaroos AY (2014) Clinical aspects and outcomes of 70 patients with Middle East respiratory syndrome coronavirus infection: a single-center experience in Saudi Arabia. Int J Infect Dis 29:301-306

114. Sacks OW (1991) Awakenings. Pan Macmillan

115. Sagui E, Janvier F, Baize S, Foissaud V, Koulibaly F, Savini H, Maugey N, Aletti M, Granier H, Carmoi T (2015) Severe Ebola virus infection with encephalopathy: evidence for direct virus involvement. Clin Infect Dis 61:1627-1628

116. Salinas S, Schiavo G, Kremer EJ (2010) A hitchhiker's guide to the nervous system: the complex journey of viruses and toxins. Nat Rev Microbiol 8:645-655 
117. Santosh CG, Bell JE, Best JJ (1995) Spinal tract pathology in AIDS: postmortem MRI correlation with neuropathology. Neuroradiology 37:134-138

118. Sartoretti-Schefer S, Blättler T, Wichmann W (1997) Spinal MRI in vacuolar myelopathy, and correlation with histopathological findings. Neuroradiology 39:865-869

119. Saylor D (2018) Neurologic complications of human immunodeficiency virus infection. Continuum (Minneap Minn) 24:1397-1421

120. Schmutzhard E, Pfausler B (2017) Neurologic complications of sepsis. Handb Clin Neurol 141:675-683

121. Schrör K (2007) Aspirin and Reye syndrome: a review of the evidence. Paediatr Drugs 9:195-204

122. Sejvar J (2014) Neuroepidemiology and the epidemiology of viral infections of the nervous system. Handb Clin Neurol 123:67-87

123. Sejvar JJ, Haddad MB, Tierney BC, Campbell GL, Marfin AA, Van Gerpen JA, Fleischauer A, Leis AA, Stokic DS, Petersen LR (2003) Neurologic manifestations and outcome of West Nile virus infection. JAMA 290:511-515

124. Sener RN (2004) Subacute sclerosing panencephalitis findings at MR imaging, diffusion MR imaging, and proton MR spectroscopy. AJNR Am J Neuroradiol 25:892-894

125. Shen WC, Chiu HH, Chow KC, Tsai CH (1999) MR imaging findings of enteroviral encephaloymelitis: an outbreak in Taiwan. AJNR Am J Neuroradiol 20:1889-1895

126. Simmons J, Pittet JF (2015) The coagulopathy of acute sepsis. Curr Opin Anaesthesiol 28:227-236

127. Smith AB, Smirniotopoulos JG, Rushing EJ (2008) Central nervous system infections associated with human immunodeficiency virus infection: radiologic-pathologic correlation. RadioGraphics 28:2033-2058

128. Sneller MC, Reilly C, Badio M, Bishop RJ, Eghrari AO, Moses SJ, Johnson KL, Gayedyu-Dennis D, Hensley LE, Higgs ES, Nath A, Tuznik K, Varughese J, Jensen KS, Dighero-Kemp B, Neaton JD, Lane HC, Fallah MP (2019) A longitudinal study of Ebola sequelae in Liberia. N Engl J Med 380:924-934

129. Solomon T, Dung NM, Vaughn DW, Kneen R, Thao LT, Raengsakulrach B, Loan HT, Day NP, Farrar J, Myint KS, Warrell MJ, James WS, Nisalak A, White NJ (2000) Neurological manifestations of dengue infection. Lancet 355:1053-1059

130. Solomon T, Lewthwaite P, Perera D, Cardosa MJ, McMinn P, Ooi MH (2010) Virology, epidemiology, pathogenesis, and control of enterovirus 71. Lancet Infect Dis 10:778-790

131. Solomon T, Vaughn DW (2002) Pathogenesis and clinical features of Japanese encephalitis and West Nile virus infections. Curr Top Microbiol Immunol 267:171-194

132. Swanson PA 2nd, McGavern DB (2015) Viral diseases of the central nervous system. Curr Opin Virol 11:44-54

133. Tabarki B, Thabet F, Al Shafi S, Al Adwani N, Chehab M, Al Shahwan S (2013) Acute necrotizing encephalopathy associated with enterovirus infection. Brain Dev 35:454-457

134. Tan CS, Koralnik IJ (2010) Progressive multifocal leukoencephalopathy and other disorders caused by JC virus: clinical features and pathogenesis. Lancet Neurol 9:425-437

135. Tan K, Patel S, Gandhi N, Chow F, Rumbaugh J, Nath A (2008) Burden of neuroinfectious diseases on the neurology service in a tertiary care center. Neurology 71:1160-1166

136. Teng GG, Chatham WW (2015) Vasculitis related to viral and other microbial agents. Best Pract Res Clin Rheumatol 29:226-243

137. Toovey S (2008) Influenza-associated central nervous system dysfunction: a literature review. Travel Med Infect Dis 6:114-124

138. Toscano G, Palmerini F, Ravaglia S, Ruiz L, Invernizzi P, Cuzzoni MG, Franciotta D, Baldanti F, Daturi R, Postorino P,
Cavallini A, Micieli G (2020) Guillain-Barré syndrome associated with SARS-CoV-2. N Engl J Med 382:2574-2576

139. Tsai L-K, Hsieh S-T, Chao C-C, Chen Y-C, Lin Y-H, Chang S-C, Chang Y-C (2004) Neuromuscular disorders in severe acute respiratory syndrome. Arch Neurol 61:1669-1673

140. Turtle L, Solomon T (2018) Japanese encephalitis-the prospects for new treatments. Nat Rev Neurol 14:298-313

141. Umapathi T, Kor AC, Venketasubramanian N, Lim CC, Pang BC, Yeo TT, Lee CC, Lim PL, Ponnudurai K, Chuah KL, Tan PH, Tai DY, Ang SP (2004) Large artery ischaemic stroke in severe acute respiratory syndrome (SARS). J Neurol 251:1227-1231

142. van Riel D, Verdijk R, Kuiken T (2015) The olfactory nerve: a shortcut for influenza and other viral diseases into the central nervous system. J Pathol 235:277-287

143. Varatharaj A, Thomas N, Ellul MA, Davies NWS, Pollak TA, Tenorio EL, Sultan M, Easton A, Breen G, Zandi M, Coles JP, Manji H, Al-Shahi Salman R, Menon DK, Nicholson TR, Benjamin LA, Carson A, Smith C, Turner MR, Solomon T, Kneen R, Pett SL, Galea I, Thomas RH, Michael BD (2020) Neurological and neuropsychiatric complications of COVID-19 in 153 patients: a UK-wide surveillance study. Lancet Psychiatry $7: 875-882$

144. Varga Z, Flammer AJ, Steiger P, Haberecker M, Andermatt R, Zinkernagel AS, Mehra MR, Schuepbach RA, Ruschitzka F, Moch H (2020) Endothelial cell infection and endotheliitis in COVID-19. Lancet 395:1417-1418

145. Venkatesan A, Michael BD, Probasco JC, Geocadin RG, Solomon $\mathrm{T}$ (2019) Acute encephalitis in immunocompetent adults. Lancet 393:702-716

146. Weaver SC, Lecuit M (2015) Chikungunya virus and the global spread of a mosquito-borne disease. N Engl J Med 372:1231-1239

147. Weiss D, Carr D, Kellachan J, Tan C, Phillips M, Bresnitz E, Layton M (2001) Clinical findings of West Nile virus infection in hospitalized patients, New York and New Jersey, 2000. Emerg Infect Dis 7:654-658

148. Widmann CN, Heneka MT (2014) Long-term cerebral consequences of sepsis. Lancet Neurol 13:630-636

149. Will RG, Ironside JW, Zeidler M, Cousens SN, Estibeiro K, Alperovitch A, Poser S, Pocchiari M, Hofman A, Smith PG (1996) A new variant of Creutzfeldt-Jakob disease in the UK. Lancet 347:921-925

150. Willison HJ, Jacobs BC, van Doorn PA (2016) Guillain-Barré syndrome. Lancet 388:717-727

151. Wong PF, Craik S, Newman P, Makan A, Srinivasan K, Crawford E, Dev D, Moudgil H, Ahmad N (2020) Lessons of the month 1: a case of rhombencephalitis as a rare complication of acute COVID-19 infection. Clin Med (Lond) 20:293-294

152. World Health Organisation (WHO) (2019) Global health observatory (GHO) data - HIV/AIDS. Retrieved from https://www. who.int/gho/hiv/en/. Accessed 7 May 2020

153. World Health Organisation (WHO) (2020) Malaria - fact sheet. Retrieved from https://www.who.int/news-room/fact-sheets/detai 1/malaria. Accessed 15 May 2020

154. World Health Organisation (WHO) (2019) Measles - fact sheet. Retrieved from https://www.who.int/news-room/fact-sheets/detai 1/measles. Accessed 4 May 2020

155. World Health Organisation (WHO) (2019) Middle East respiratory syndrome coronavirus (MERS-CoV). Retrieved from https:// www.who.int/emergencies/mers-cov/en/. Accessed 10 May 2020

156. World Health Organisation (WHO) (2017) Plague. Retrieved from https://www.who.int/news-room/fact-sheets/detail/plague. Accessed 5 May 2020

157. Xu J, Zhong S, Liu J, Li L, Li Y, Wu X, Li Z, Deng P, Zhang J, Zhong N, Ding Y, Jiang Y (2005) Detection of severe acute 
respiratory syndrome coronavirus in the brain: potential role of the chemokine mig in pathogenesis. Clin Infect Dis 41:1089-1096

158. Yang R (2018) Plague: recognition, treatment, and prevention. J Clin Microbiol 56:e01519-e11517

159. Ye M, Ren Y, Lv T (2020) Encephalitis as a clinical manifestation of COVID-19. Brain Behav Immun. 88:945-946. https://doi. org/10.1016/j.bbi.2020.04.017

160. Yeh EA, Collins A, Cohen ME, Duffner PK, Faden H (2004) Detection of coronavirus in the central nervous system of a child with acute disseminated encephalomyelitis. Pediatrics 113:e73-76

161. Zacharia TT, Law M, Naidich TP, Leeds NE (2008) Central nervous system lymphoma characterization by diffusion-weighted imaging and MR spectroscopy. J Neuroimaging 18:411-417

162. Zanin L, Saraceno G, Panciani PP, Renisi G, Signorini L, Migliorati K, Fontanella MM (2020) SARS-CoV-2 can induce brain and spine demyelinating lesions. Acta Neurochir (Wien). 162(7):1491-1494. https://doi.org/10.1007/s00701-020-04374-X
163. Zhang G, Zhang J, Wang B, Zhu X, Wang Q, Qiu S (2020) Analysis of clinical characteristics and laboratory findings of 95 cases of 2019 novel coronavirus pneumonia in Wuhan, China: a retrospective analysis. Respir Res 21:74

164. Zhang Y, Xiao M, Zhang S, Xia P, Cao W, Jiang W, Chen H, Ding X, Zhao H, Zhang H, Wang C, Zhao J, Sun X, Tian R, Wu W, Wu D, Ma J, Chen Y, Zhang D, Xie J, Yan X, Zhou X, Liu Z, Wang J, Du B, Qin Y, Gao P, Qin X, Xu Y, Zhang W, Li T, Zhang F, Zhao Y, Li Y, Zhang S (2020) Coagulopathy and antiphospholipid antibodies in patients with Covid-19. N Engl $\mathrm{J}$ Med 382(17):e38. https://doi.org/10.1056/NEJMc2007575

165. Zubair AS, McAlpine LS, Gardin T, Farhadian S, Kuruvilla DE, Spudich S (2020) Neuropathogenesis and neurologic manifestations of the coronaviruses inthe age of corona virus disease 2019: a review. JAMA Neurol 77(8):1018-1027. https://doi. org/10.1001/jamaneurol.2020.2065 